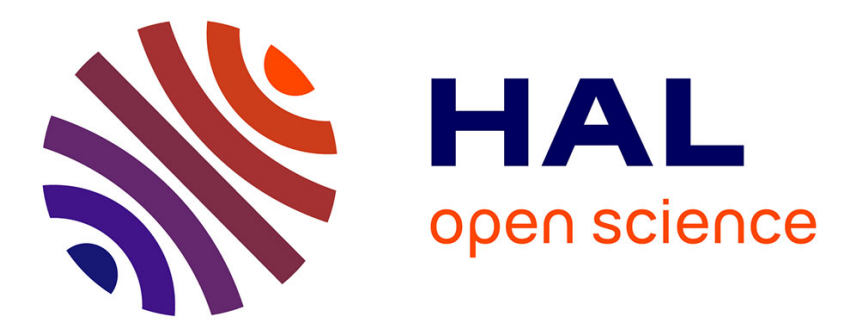

\title{
Mechanisms of the intensification of the upwelling-favorable winds during El Niño 1997-1998 in the Peruvian upwelling system
}

Adolfo Chamorro Gomez, Vincent Echevin, François Colas, Véra Oerder, Jorge Tam, Carlos Quispe-Ccalluari

\section{To cite this version:}

Adolfo Chamorro Gomez, Vincent Echevin, François Colas, Véra Oerder, Jorge Tam, et al.. Mechanisms of the intensification of the upwelling-favorable winds during El Niño 1997-1998 in the Peruvian upwelling system. Climate Dynamics, 2018, 51 (9-10), pp.3717-3733. 10.1007/s00382-018-4106-6 . hal-01957278

\section{HAL Id: hal-01957278 \\ https://hal.sorbonne-universite.fr/hal-01957278}

Submitted on 17 Dec 2018

HAL is a multi-disciplinary open access archive for the deposit and dissemination of scientific research documents, whether they are published or not. The documents may come from teaching and research institutions in France or abroad, or from public or private research centers.
L'archive ouverte pluridisciplinaire HAL, est destinée au dépôt et à la diffusion de documents scientifiques de niveau recherche, publiés ou non, émanant des établissements d'enseignement et de recherche français ou étrangers, des laboratoires publics ou privés. 
1 Mechanisms of the intensification of the upwelling-favorable winds during El Niño 1997-1998 in the 2 Peruvian Upwelling System

4 Adolfo Chamorro (1,2), Vincent Echevin (2), Francois Colas (2), Vera Oerder (2,3), Jorge Tam (1), Carlos

5 Quispe-Ccalluari (1)

6

7 email: achamorro@imarpe.gob.pe

8

9 (1) Instituto del Mar del Perú (IMARPE), Callao, Perú

10 (2) LOCEAN-IPSL, IRD/CNRS/MNHN/UPMC, UMR7159, Paris, France

11 (3) Instituto Milenio de Oceanografía (IMO-Chile), Universidad de Concepción, Concepción, Chile

13 Abstract. The physical processes driving the wind intensification in a coastal band of $\sim 100 \mathrm{~km}$ off Peru during 14 the intense 1997-1998 El Niño (EN) event were studied using a regional atmospheric model. A simulation 15 performed for the period 1994-2000 reproduced the coastal wind response to local sea surface temperature (SST) 16 forcing and large scale atmospheric conditions. The model, evaluated with satellite data, represented well the 17 intensity, seasonal and interannual variability of alongshore (i.e. NW-SE) winds. An alongshore momentum 18 budget showed that the pressure gradient was the dominant force driving the surface wind acceleration. The 19 pressure gradient tended to accelerate the coastal wind, while turbulent vertical mixing decelerated it. A quasi20 linear relation between surface wind and pressure gradient anomalies was found. Alongshore pressure gradient 21 anomalies were caused by a greater increase in near-surface air temperature off the northern coast than off the 22 southern coast, associated with the inhomogeneous SST warming. Vertical profiles of wind, mixing coefficient,

23 and momentum trends showed that the surface wind intensification was not caused by the increase of turbulence

24 in the planetary boundary layer. Moreover, the temperature inversion in the vertical mitigated the development of

25 pressure gradient due to air convection during part of the event. Sensitivity experiments allowed to isolate the

26 respective impacts of the local SST forcing and large scale condition on the coastal wind intensification. It was

27 primarily driven by the local SST forcing whereas large scale variability associated with the South Pacific

28 Anticyclone modulated its effects. Examination of other EN events using reanalysis data confirmed that

29 intensifications of alongshore wind off Peru were associated with SST alongshore gradient anomalies, as during 


\section{Keywords}

33 Ocean-atmosphere interactions; Coastal winds; El Niño 1997/1998; Peruvian Upwelling System

\section{1. Introduction}

36 The Peruvian Upwelling System is one of the major upwelling systems of the world in terms of fisheries (Zuta

37 and Guillen 1970; Chavez et al. 2008). A key oceanic process in this nearshore marine environment is the

38 upwelling of deep, nutrient-replete, cold water to the surface forced by Ekman divergence associated with

39 predominantly equatorward coastal winds. As in other upwelling regions, it is characterized by an intense

40 biological productivity (Chavez \& Messié 2009) and strong air-sea interactions (e.g. Halpern 2002; Boé et al.

41 2011; Oerder et al. 2016). A unique aspect of the Peruvian system is its proximity to the equator in the Eastern

42 Pacific, which places it directly under the influence of El Niño events (EN hereafter). During the so called

43 "canonical" EN events, warm surface waters accumulate in the Eastern Tropical Pacific off the Ecuador and Peru

44 coasts (e.g. Picaut et al. 2002) causing a dramatic reduction of the upwelling of cold water (e.g. Colas et al.

45 2008). The upwelling reduction is somewhat mitigated by an increase of the equatorward coastal wind (Wyrtki

46 1975; Kessler 2006). This local wind increase is seemingly paradoxical since large-scale trade winds are

47 weakened in the equatorial (Bjerknes 1966) and subtropical (Rahn et al. 2012) regions. Figure 1a shows the

48 mean spatial distribution of the wind anomalies off Peru coast during the strongest El Niño event observed to

49 date, between November 1997 and February 1998. Positive wind anomalies were maximum onshore and

50 decreased offshore. Negative wind anomalies at the equator indicate the weakening of the southerly trade winds

51 in the equatorial Pacific. The strongest alongshore positive wind anomalies reached $\sim 1.5 \mathrm{~m} \mathrm{~s}^{-1}$ during November

52 1997-February 1998 which represents a $40 \%$ increase with respect to the mean climatological conditions

53 (Figure 1b). Note that in the present work, anomalies were computed with respect to mean climatological

54 conditions over the 1994-2000 period.

55

56 The processes that drive the nearshore wind increase during EN have not been studied in detail. Previous studies

57 suggested that the wind intensification could be driven by a strengthening of the cross-shore pressure gradient

58 (supporting a geostrophic wind) owing to an enhanced cross-shore thermal contrast between land and sea (Bakun 
59 1990; Bakun et al. 2010). This enhanced thermal contrast would be caused by a stronger temperature increase

60 over land than over sea during EN, due to the greenhouse effect induced by moist air. On the other hand, Enfield

61 (1981) suggested that the enhanced cross-shore thermal contrast during EN was forced by a stronger shortwave

62 heating over land associated with a reduction of nearshore cloudiness. However, SST gradients may also impact

63 on surface winds. Lindzen and Nigam (1987) showed that surface winds over the tropical Pacific can be forced

64 by SST gradients at relatively large scale. Kessler (2006) suggested that the alongshore SST gradient which

65 appears off the Peru coasts during EN may drive a strengthening of the alongshore pressure gradient and wind,

66 but the mechanisms were not studied. In addition, the enhanced atmospheric turbulence due to the surface ocean

67 warming may result in the downward vertical mixing of momentum from the upper layers of the atmosphere to

68 the ocean surface, thus increasing the surface wind (e.g. Wallace et al. 1989).

69

70 Large scale atmospheric circulation is also impacted by EN, which may affect coastal winds through

71 modifications of the South Pacific Anticyclone (SPA). Dewitte et al. (2011) showed that the alongshore wind

72 intraseasonal (i.e. 10-60 days band) variability off central Peru $\left(\sim 15^{\circ} S\right)$ was forced by migratory disturbances

73 across the SPA. Rahn et al. (2012) showed that the SPA was weaker during EN, resulting in decreasing winds off

74 central Chile. Such weakening might mitigate the coastal wind increase during EN off Peru, and a poleward

75 displacement of the SPA might have a similar effect, as shown by Belmadani et al. (2014) in the context of

76 climate change. However, the influence of large-scale atmospheric circulation interannual variability on the

77 coastal winds off Peru remains to be extensively investigated.

78

79 In this paper, a regional atmospheric model forced by realistic oceanic (i.e. Sea Surface Temperature) and lateral

80 boundary conditions was used to investigate the physical processes driving the coastal wind intensification

81 during the strong 1997-1998, "eastern pacific" El Niño event. The respective roles of the large scale signal and

82 SST local forcing on the alongshore wind anomalies were also studied for this particular event. Data and

83 methods are described in section 2. Results are presented in section 3, and discussion and conclusions are given 84 in section 4 .

85

86 2. Data and Methods

$87 \quad 2.1$ Regional atmospheric model 
88 The Weather Research and Forecasting (WRF) model version 3.3.1 (Skamarock and Klemp 2008) was used to

89 simulate the coastal wind during the period 1994-2000, which includes the very strong 1997-1998 El Niño event

90 (McPhaden 1999). WRF is a fully compressible and nonhydrostatic model. Its vertical coordinate is a terrain-

91 following hydrostatic pressure coordinate. The model uses a time-split integration scheme. Slow and low-

92 frecuency modes are integrated using a Runge-Kutta 3rd order time integration scheme, while the high-frecuency

93 acoustic modes are integrated over smaller time steps to maintain numerical stability. For spatial discretization

94 the model uses a 5th order upwind biased advection schemes. Two nested domains, with one-way offline nesting,

95 were used (Fig.2). The large domain has a resolution of $0.75^{\circ}$ and encompasses the South East Pacific and the

96 main part of South America. The small domain has a resolution of $0.25^{\circ}$ and covers the Peru and Northern Chile

97 region $\left(30^{\circ} \mathrm{S}-12^{\circ} \mathrm{N}\right)$. Both domains include the Andes. The relatively high resolution of the nested domain allows

98 to better represent the orography (Fig. 2), a crucial element of the regional dynamics (e.g. Xue et al. 2004). Both

99 grids have 60 vertical sigma levels between the surface and the top of the atmosphere (defined by the $50 \mathrm{hPa}$ top

100 pressure), with 21 levels in the first $\sim 1000 \mathrm{~m}$. The time steps for the large and nested domains are $180 \mathrm{~s}$ and 60

101 s, respectively.

102

103 The parameterizations for short and long wave radiation, cloud physics, land surface and planetary boundary

104 layer (PBL) used in this study are listed in Table 1. Most of them (except the Dudhia (1989) shortwave radiation

105 scheme) are identical to those in the $1 / 12^{\circ}$ configuration of Oerder et al. (2016) for the Peru-northern Chile

106 region. The ERA-interim reanalysis data (Dee et al. 2011), 6-hourly, were used as initial and boundary

107 conditions. The daily Optimum Interpolation Sea Surface Temperature (OISST) at $0.25^{\circ}$ (Reynolds et al. 2007)

108 was used as SST forcing. Diurnal SST variations are accounted for in our simulations by using the Zeng and

109 Beljaars (2005) slab model that is included in WRF. Model outputs were recorded every six hours using

110 instantaneous and average values.

111

\section{$112 \quad 2.2$ Observational data}

113 Observations from two different satellite-borne scatterometers were used to evaluate the realism of the model

114 surface winds: the ERS weekly wind fields at $1^{\circ} \times 1^{\circ}$ resolution over the period 1992-2000 and a monthly

115 climatology of QuikSCAT wind fields (hereafter QSCAT) at $1 / 2^{\circ} \times 1 / 2^{\circ}$ resolution grids. The two products were

116 processed by CERSAT (2002a,b) and downloaded from www.ifremer.fr/cersat. Surface winds were interpolated 
on the $1 / 4^{\circ}$ model grid.

119 Daily SST and output from ERA-interim reanalysis (see above) were also used in the analysis.

\section{$121 \quad 2.3$ Monthly momentum budget}

122 In order to investigate the dominant forces that induce the monthly wind changes, we used the following relation

123 demonstrated in Madec (2008; for the NEMO ocean model) and Oerder et al. (2016):

$124 \frac{\langle V\rangle-V\left(t_{0}\right)}{\Delta \mathrm{t}}=\sum_{F_{n} \in\{\text { forces }\}}\left[F_{n}\right]$

125 where $\langle V\rangle$ is the monthly mean wind, $V\left(t_{o}\right)$ is the initial velocity at the beginning of the month, $\Delta$ tthe time

126 step, and $F_{n}$ the momentum terms: advection $(\vec{v} \cdot \vec{\nabla}) \vec{v}$, vertical mixing $\frac{\partial}{\partial z}\left(\frac{\vec{\tau}}{\rho}\right)$, Coriolis $-f \vec{k} \times \vec{v}$ and pressure

127 gradient $\frac{-1}{\rho} \vec{\nabla} P$. The bracket $([\quad])$ is a the double time averaging operator defined as:

$128 \quad\left[F_{n}\right]=\frac{1}{\mathrm{~N}+1} \sum_{\mathrm{p}=0}^{N}\left(\sum_{\mathrm{k}=1}^{p} F_{n}\right)$

129 with $\mathrm{N}$ the number of time steps during one month.

130 Based on Eq. (1), we obtain the following relation for two consecutive months ( $M$ and $M+1)$ :

$131\langle V\rangle_{\mathrm{M}+1}-\langle V\rangle_{M}=\mathrm{V}\left(t_{0, \mathrm{M}+1}\right)-V\left(t_{0, \mathrm{M}}\right)+\sum_{F_{n} \in\{\text { forces }\}} \Delta \mathrm{t}\left(\left[F_{n}\right]_{\mathrm{M}+1}-\left[F_{n}\right]_{M}\right)$

132 On the other hand, a simple integration of the momentum equation between $t_{0, M}$ and $t_{0, M+1}$ (i.e. the respective

133 dates corresponding to the beginning of months $\mathrm{M}$ and $\mathrm{M}+1$ ) leads to:

$134 V\left(t_{0, \mathrm{M}+1}\right)-V\left(t_{0, \mathrm{M}}\right)=\Delta \mathrm{t} \sum_{F_{n} \in\{\text { Forces }\}}\left\langle F_{n}\right\rangle$

135 Thus $\left\langle F_{n}\right\rangle$ is the time average of the forces between the beginning of the month $\left(\mathrm{t}_{0, \mathrm{M}}\right)$ and the beginning of the

136 following month $\left(\mathrm{t}_{0, \mathrm{M}+1}\right)$.

137 Finally, replacing Eq. (4) in Eq. (3), we obtain:

$138\langle V\rangle_{\mathrm{M}+1}-\langle V\rangle_{M}=\sum_{F_{n} \in\{\text { forces }\}} \Delta \mathrm{t}\left(\left[F_{n}\right]_{\mathrm{M}+1}-\left[F_{n}\right]_{M}+\left\langle F_{n}\right\rangle\right)$

139 The left side of Eq. (5) represents the change of the monthly mean wind (from month $M$ to month $M+1$ ) and the

140 right side represents the sum of the forces contribution. We computed the anomalies of the alongshore (i.e.

141 parallel to the WRF model smoothed coastline oriented in the NW-SE direction) component of Eq. (5) (with

142 respect to the "climatology" over 1994-2000, i.e. the average over all years of the difference of one month from 
143 its predecessor) in a coastal band of one degree width (4 grid points of the nested domain). This coastal band

144 fully covers the upwelling area which offshore extension is controlled by the shelf topography (Estrade et al.

145 2008) and does not exceed the Rossby radius of deformation (around $120 \mathrm{~km}$ off Peru, e.g. Chavez and Barber

146 1987). In this area were observed the maximum wind anomalies during the 1997-98 EN (Fig. 1a). WRF code

147 modifications were necessary to save online the individual tendency terms of the momentum balance at each

148 model time step. However modification of the tendency terms due to high-frequency acoustic modes were not

149 saved, which explains why an exact closure of the momentum balance can not be expected.

\section{$151 \quad 2.4$ Virtual temperature}

152 Virtual temperature is computed in order to estimate the relative contribution of humidity to air density and

153 pressure during EN. The virtual temperature of moist air is the temperature that dry air should have to reach a

154 total pressure and density equal to those of the moist air (Wallace and Hobbs 2006). It is defined by:

$155 T_{v}=\mathrm{T} *\left(1+0.61 * Q_{v}\right)$

156 with $\mathrm{T}$ the air temperature and $\mathrm{Q}_{\mathrm{v}}$ the mixing ratio, which describes humidity.

157 We computed the monthly virtual temperature anomaly as:

$158 \quad T_{v}{ }^{\prime}=\left(1+0.61 * \overline{Q_{v}}\right) * \mathrm{~T}^{\prime}+(\bar{T} * 0.61) * Q_{v}{ }^{\prime}(7)$

159 with primes marking the monthly anomalies and overlines marking the monthly means. The two terms on the

160 right side of Eq. (7) represent the relative contribution of air temperature and humidity anomalies to the virtual

161 temperature anomaly. Given that virtual temperature is directly proportional to the pressure (for a fixed mass of

162 gas, at a constant volume), these terms contribute to the atmospheric pressure.

\subsection{Model simulations}

165 We carried out three experiments with the WRF model. First, a control run was performed over the 1994-2000

166 period. Then, two experiments (BRY-EN and SST-EN) were performed to isolate the role of the large scale

167 signal from the role of the SST local forcing. The BRY-EN experiment was carried out using the 6-hourly

168 atmospheric boundary conditions from the years 1997-1998 (Niño boundary conditions) and daily SST forcing

169 from the years 1994-1995 (so-called SST neutral conditions) to isolate the role of the large scale signal. The

170 SST-EN experiment was performed using the 6-hourly atmospheric boundary conditions from the years 1994-

1711995 (neutral boundary conditions) and daily SST forcing from the years 1997-1998 (SST Niño conditions) to 
172 isolate the role of the SST local forcing. Note that the 1994-1995 period is considered here as "neutral

173 conditions" for the Peru region as it did not present strong anomalies with respect to climatological conditions, in

174 spite of the occurrence of a weak Central Pacific El Niño in austral spring 1994 and summer 1995.

175

$176 \quad 2.6$ Statistical significance

177 For each of the correlations between two variables presented in the following, the Pearson correlation coefficient

178 (r) was used to measure the strength of a linear association between the variables, and the p-value was used to

179 determine the statistical significance of the relationship.

181 3. Results

\section{3.1 Validation}

183 3.1.1 Mean and annual cycle of the surface wind

184 The simulated surface winds were compared with ERS and QSCAT observations. Figures 3 a-c show the annual

185 mean surface wind field obtained from both satellites and the model for the year 2000, when the two satellite

186 observation periods were overlapping. South of the equatorial line, the observed surface winds were strong ( $\sim 6-8$

$187 \mathrm{~m} \mathrm{~s}^{-1}$ ) and they blowed north-westward over the oceanic region. They were weaker and approximately parallel

188 to the coastline in the nearshore region, with a maximum $\left(\sim 5-6 \mathrm{~m} \mathrm{~s}^{-1}\right)$ near $15^{\circ} \mathrm{S}$ and minimum $\left(\sim 3-4 \mathrm{~m} \mathrm{~s}^{-1}\right)$ near

$18918^{\circ} \mathrm{S}$ (Figs. 3a,c). The model reproduced the observed wind spatial patterns, with a wind intensity closest to that

190 of QSCAT. However, the wind drop-off (i.e. wind decrease towards the coast, e.g. Capet et al., 2004) was poorly

191 simulated, especially between $10^{\circ} \mathrm{S}$ and $16^{\circ} \mathrm{S}$. It is stronger in QSCAT than in ERS, and both satellites have a

192 blind zone near the coast of approximately $25 \mathrm{~km}$ and $50 \mathrm{~km}$ respectively where no data are available. Note that

193 wind speed was lower in ERS than QSCAT by $\sim 0.5 \mathrm{~m} \mathrm{~s}^{-1}$ over a large part of the model domain, but that the

194 wind directions were consistent. The differences in wind intensity between ERS and QSCAT are attributed to the

195 use of different operating frequencies, different temporal sampling of the satellites, and gridded products with

196 different spatial resolutions (Bentamy et al. 2013).

197

198 Figures 3 d-f show the climatological mean annual cycle of the alongshore wind near the Peru coast. The

199 seasonal cycles were computed over the same time period for ERS and the model (1994-2000), but different time

200 period for QSCAT (2000-2008). The observed alongshore winds were strongest during austral winter (July- 
201 September) and early spring (October) around $15^{\circ} \mathrm{S}$. The model wind climatology was in relatively good 202 agreement with the satellite wind climalogies (Pearson's $r>0.85, \mathrm{p}<0.01$ ). It reproduced the local maximun 203 values (coastal jets) near $4^{\circ} \mathrm{S}$ and $15^{\circ} \mathrm{S}$ which are both seen in QSCAT but not in ERS. ERS did not capture the 204 local maximum at $4^{\circ} \mathrm{S}$ likely due to its lower spatial resolution. The model overestimated the intensity of the 205 alongshore wind with respect to ERS and QSCAT between $3^{\circ} \mathrm{S}$ and $17^{\circ} \mathrm{S}$, and slightly underestimated it with 206 respect to QSCAT in the equatorial region $\left(0-2^{\circ} \mathrm{S}\right)$.

208 3.1.2 Wind and temperature cross-shore vertical structures

209 The meridional wind and temperature cross-shore vertical structures in the central Peru (at $\sim 15^{\circ} \mathrm{S}$ ) simulated by 210 the model were compared against the ERA-interim reanalysis data (Figure 4). Reanalysis data showed the 211 coastal jet core located a height of $\sim 250 \mathrm{~m}$ and within the first $100 \mathrm{~km}$ from the coast, with a wind intensity of

$212 \sim 8 \mathrm{~m} \mathrm{~s}^{-1}$ (Fig.4a). The coastal jet is capped by a temperature inversion, which base is located at $\sim 600 \mathrm{~m}$ above 213 sea level nearshore. The model reproduced relatively well the intensity of the coastal jet core, although with a 214 position much closer to the coast. In overall, the vertical structures of wind and temperature were well 215 reproduced by the model in the first $\sim 1000 \mathrm{~m}$. Note that the steep topography of the Andes is logically 216 represented with greater detail in the WRF model (Fig. 4b).

218 3.1.3 Surface winds and SST anomalies during El Niño

219 The model reproduced the spatial structure of the wind anomalies off Peru (north of $\sim 20^{\circ} \mathrm{S}$ ) during November 220 1997-February 1998 (Fig. 5a) found in the satellite observations (Fig. 1b). Persistent positive (equatorward) 221 alongshore wind anomalies occured from April 1997 to October 1998 (Fig. 5b) in the $5^{\circ} \mathrm{S}-10^{\circ} \mathrm{S}$ latitude band. 222 There was a short relaxation period in August 1997 with weak negative anomalies south of $10^{\circ} \mathrm{S}$. The strongest 223 positive anomalies $\left(>1.5 \mathrm{~m} \mathrm{~s}^{-1}\right)$ occured between November 1997 and March 1998. Furthermore, strong negative 224 anomalies $\left(<-1 \mathrm{~m} \mathrm{~s}^{-1}\right)$ occured in December 1997 - February 1998 north of $5^{\circ} \mathrm{S}$. The general pattern of 225 alongshore wind anomalies from the model was consistent with that from ERS (Fig. 1b). However, some 226 discrepancies were found, such as an overestimation of modelled wind anomalies in May-June 1997 and an 227 underestimation in January 1997. Strong SST positive anomalies $\left(>3^{\circ} \mathrm{C}\right)$ were seen between May 1997 and May 2281998 along the equator in the Eastern Pacific and along the Peru coast (Fig. 5c), with two main peaks $\left(>4^{\circ} \mathrm{C}\right)$ 229 between $5^{\circ} \mathrm{S}$ and $10^{\circ} \mathrm{S}$ in July-August 1997 and November 1997-April 1998 (Fig. 5d). These peaks were related 
230 to the poleward propagation of downwelling coastal-trapped waves, which strongly deepened the thermocline

231 during EN, shutting down the upwelling of cold water (Colas et al., 2008). The amplitude of the SST anomalies

232 slightly reduced in September-October 1997 but remained quite strong $\left(>3^{\circ} \mathrm{C}\right)$. Note that although the two SST

233 anomaly peaks were of a relatively similar amplitude, only the second peak was synchronous with strong wind

234 anomalies (>1.5 $\mathrm{m} \mathrm{s}^{-1}$, Fig. 5a) during November 97-April 98, whereas the wind response to the first peak in

235 July-August 1997 was weaker $\left(<1 \mathrm{~m} \mathrm{~s}^{-1}\right.$ in the model and less than $0.5 \mathrm{~m} \mathrm{~s}^{-1}$ in ERS; Fig. 1b). Besides, the model

236 also reproduced the negative wind anomalies north of $5^{\circ} \mathrm{S}$ between November 1997 and April 1998, a period

237 during which SST anomalies were positive.

\section{3.2 Alongshore momentum budget}

240 First, in order to investigate the spatial patterns of the forces that induced the wind anomalies off Peru during

241 EN, we computed the anomalies of the meridional component of the forces (involved in the meridional monthly

242 momentum budget, see Eq. 5) in the first layer of the model for the whole domain. Each term was then averaged

243 for the period November 1997-February 1998 (Figs. 6a-d). Second, we computed the monthly alongshore

244 anomalies of the forces (i.e. both zonal and meridional components were used in the projection along the NW-SE

245 direction) and averaged them in a coastal band for the entire EN period (Fig. 6e).

247 Comparison of anomalies of advection, vertical shear of the meridional turbulent stress (hereafter named vertical

248 mixing term), pressure gradient and Coriolis terms shows that pressure gradient and vertical mixing were the

249 dominant forces (Figs. 6b,c). The pressure gradient anomaly was positive (Fig. 6c), thus accelerated the

250 equatorward wind during EN. Expectedly, vertical mixing anomaly was opposed to the equatorward wind thus

251 negative (Fig. 6b). The two terms almost balanced each other everywhere in the domain, except in the region

252 between $0-5^{\circ} \mathrm{S}$ where advection anomaly was relatively strong (Fig. 6a) and pressure gradient and vertical

253 mixing anomalies were much weaker. Coriolis term anomalies had much smaller values (Fig. 6d).

255 Figure 6e shows the time evolution of the monthly anomalies of the surface forces projected in the alongshore

256 direction. The terms were averaged in a one-degree-wide coastal band between $7^{\circ} \mathrm{S}$ and $15^{\circ} \mathrm{S}$ (this coastal region

257 was chosen because the coastline is relatively rectilinear and the wind anomalies were relatively homogeneous in

258 space). The pressure gradient and vertical mixing were the main forces during the entire time period. The dates 
corresponding to pressure gradient maximum (positive anomalies) values coincided with those of vertical mixing

260 minimum (negative anomalies) values (e.g. in June-July and November-December 1997 and April-May 1998).

261 The advection term was weaker, except in July-September and October-November 1997. The contribution of the

262 Coriolis force was negligible during the entire period. The tendency ( $\Delta \mathrm{V}^{\prime}$ : month to month wind anomaly

263 difference) was almost equal to the sum of all terms, showing that the budget (see Eq. (5) in section 2.3) is

264 virtually closed. The small differences in the budget (RMS error of $\sim 6 \%$ over the simulation period) come from

265 the acoustic correction (see sections 2.1 and 2.3).

267 The wind intensification during EN occurred during different phases (Fig. 6e, dashed-black line). It began in 268 March 1997 ( $\Delta \mathrm{V}^{\prime} \sim 1 \mathrm{~m} \mathrm{~s}^{-1}$ from March to April 1997) and was maintained until June 1997, due to a positive 269 equatorward pressure force stronger than the sum of the other (negative) terms. The wind anomaly then strongly 270 decreased $\left(\Delta \mathrm{V}^{\prime} \sim-1.2 \mathrm{~m} \mathrm{~s}^{-1}\right.$ from June to July 1997) due to a negative advection of momentum between June and 271 August 1997, which was related to the large scale forcing. A similar momentum budget for the BRY-EN 272 experiment confirmed this large scale modulation (figure not shown). The wind acceleration became strong 273 again in September $1997\left(\Delta \mathrm{V}^{\prime} \sim 1.5 \mathrm{~m} \mathrm{~s}^{-1}\right.$ from September to October), when advection weakened and the 274 pressure gradient dominated the other forces. The tendency was weak from January to May 1998. In the later 275 phase of EN, the wind anomaly was strongly reduced from May to July 1998, due to a decrease of the pressure 276 gradient.

278 Consistently with previous studies (Muñoz and Garreaud, 2005; Belmadani et al., 2014), alongshore pressure 279 gradient anomalies were highly correlated $(\mathrm{r}=0.8, \mathrm{p}<0.01)$ with alongshore wind anomalies averaged over the 280 coastal band (line red and dashed-black line in Fig. 6e). Although it displays smaller spatial scales than the 281 alongshore wind, the pressure gradient explains relatively well the wind intensification between $5^{\circ} \mathrm{S}$ and $16^{\circ} \mathrm{S}$ 282 during the peak of EN but also over limited portions of the coast in June 1997 and August 1998 (Fig.7a). More 283 specifically, a strong correlation $(\mathrm{r}=\sim 0.75, \mathrm{p}<0.01)$ between alongshore pressure gradient anomalies and 284 alongshore wind anomalies was found along the coast for latitudes between $4^{\circ} \mathrm{S}$ and $18^{\circ} \mathrm{S}$ (Fig. $7 \mathrm{~b}$ ). In this 285 sense, on average over a coastal band $\left(7^{\circ} \mathrm{S}-15^{\circ} \mathrm{S}\right) \sim 64 \%$ of the temporal variability of the wind anomalies was 286 explained by pressure gradient anomalies, suggesting that vertical mixing behaved like a linear bottom frictional

287 term equilibrating the pressure gradient. This led to the following relation $\mathrm{V}=\frac{-1}{\mathrm{c} \rho} \frac{\partial P}{\partial y}$ with $\mathrm{c}$ the linear friction 
288 coefficient and $\rho$ the surface air density. From our model results, $\mathrm{c}$ was $\sim 410^{-5} \mathrm{~s}^{-1}$, thus comparable to Muñoz

289 and Garreaud (2005)'s estimation for the Chile central coast $\left(\mathrm{c} \sim 510^{-5} \mathrm{~s}^{-1}\right)$. The steep orography of the Andes

290 precluded the development of an anomalous cross shore flow, thus the alongshore pressure gradient can not be

291 equilibrated by the Coriolis force. Consequently the alongshore flow built up until the frictional force (i.e.

292 vertical mixing term) balanced the alongshore pressure gradient.

294 In summary, the pressure gradient term played a major role in initiating and terminating the wind anomaly

295 during this EN event. In the next sections we study in detail the processes that drive the pressure gradient 296 increase at the beginning of the event.

\section{3.3 Air temperature and humidity contributions to the alongshore pressure gradient}

299 As surface pressure is related to virtual temperature in the air column (see Section 2.4), we examined the relative

300 contributions of temperature and humidity anomalies to the virtual temperature anomalies (VTA) (see Eq. (7) in 301 section 2.4) during EN (November 1997-February 1998). The VTA distribution displayed the largest positive 302 anomalies $\left(>4^{\circ} \mathrm{K}\right.$ ) along the north coast between $4^{\circ} \mathrm{S}$ and $8^{\circ} \mathrm{S}$ and in the lowest $300 \mathrm{~m}$ (Fig. 8a). Temperature 303 variations dominated VTA (Fig. 8b), while humidity anomalies contributed to at most $\sim 15 \%$ of the VTA (north 304 coast around $400 \mathrm{~m}$, Fig.8c). The humidity anomaly was stronger at $400 \mathrm{~m}$ because humidity was higher and 305 nearly constant from the surface up to $\sim 400 \mathrm{~m}$ before decreasing progressively with altitude during EN, whereas 306 it progressively decreased with altitude with a relatively constant vertical gradient from the surface to $900 \mathrm{~m}$ 307 under mean climatological conditions (Fig. 8d). These results show that the stronger temperature increase in the 308 north of Peru was the main driver of the alongshore pressure gradient anomaly during the EN event, while 309 humidity did not play an important role.

310 This thermally driven pressure gradient was confirmed by the high correlation $(r=0.84, p<0.01)$ between the 311 surface wind anomaly in the coastal band and the alongshore SST gradient (Fig. 9). This correlation was slightly 312 higher (0.87) with a 1 month lag (when the SST gradient leads the wind). This suggests that the anomalously 313 warm surface ocean forced the low atmosphere by heating the air column more in the north than in the south, 314 thus generating the pressure gradient that drove the equatorward wind anomaly. 


\subsection{Downward mixing of momentum during EN}

318 Due to the air warming and humidification associated with the presence of anomalously warm surface waters in

319 the nearshore region, shallow convection was enhanced. In the coastal band, the planetary boundary layer height 320 (PBLH) increased by $200 \mathrm{~m}(\sim 50 \%)$ around June 97 and by $\sim 100-150 \mathrm{~m}(\sim 100 \%)$ between December 1997-

321 March 1998 (Fig. 10). The PBLH increases were in phase with the SST anomalies peaks, and slightly stronger in 322 the north than in the south, in agreement with the SST spatial changes (not shown).

324 Given this PBL variability, a potential mechanism for the wind intensification could be associated with the 325 increase of turbulence in the PBL during EN, which may generate a more efficient downward vertical flux of 326 momentum (Wallace et al. 1989). However, turbulent mixing tended to decelerate the wind even more during the 327 warm EN phases (Fig. 6e). To further investigate why Wallace et al. (1989)'s mechanism can not explain the EN 328 wind increase, we examined the vertical profiles of alongshore wind, turbulent vertical mixing coefficient, 329 momentum budget forces contribution, and temperature during climatological and EN conditions in November 330 1997-February 1998 (Fig. 11). The wind intensification during EN occurred between the sea surface and 1600 $331 \mathrm{~m}$ (black line in Fig. 11a). The wind maximum $\left(\sim 8 \mathrm{~m} \mathrm{~s}^{-1}\right)$ shifted from $\sim 300 \mathrm{~m}$ in mean climatological conditions 332 to $\sim 500 \mathrm{~m}$. There was a decrease of wind shear ( $\mathrm{dV} / \mathrm{dz}$ ) below $\sim 500 \mathrm{~m}$ during EN, mainly due to the velocity 333 increase at the surface $(20 \%)$ and a virtually unchanged velocity at $300 \mathrm{~m}$ (black line in Fig. 11a). Turbulent 334 vertical mixing coefficient $\left(\mathrm{K}_{\mathrm{z}}\right)$ increased almost twofold during EN reaching a maximum of $\sim 40 \mathrm{~m}^{2} \cdot \mathrm{s}^{-1}$ at $200 \mathrm{~m}$ $335\left(\sim 15 \mathrm{~m}^{2} \mathrm{~s}^{-1}\right.$ in climatological conditions, blue line in Fig. 11a). The impact on the turbulent stress $\left(\tau=\mathrm{K}_{\mathrm{z}} \cdot \mathrm{dV} / \mathrm{dz}\right)$ 336 of the wind shear decrease and turbulent vertical mixing $\left(\mathrm{K}_{\mathrm{z}}\right)$ increase was such that the momentum vertical 337 mixing term $(\mathrm{d} \tau / \mathrm{dz})$ reduced ( it is negative in mean climatological conditions, blue line in Fig $11 \mathrm{~b}$ and $12 \mathrm{~b}$ ) 338 during EN conditions (Fig. 6e; blue line in Fig. 11c). This also shows that the EN wind intensification near the 339 surface was not driven by downward mixing of momentum. The pressure gradient (positive in mean 340 climatological conditions, red line in Fig. $11 \mathrm{~b}$ and 12b) increase was maximum at the surface and decreased with 341 height during EN conditions (red line in Fig. 11c). The Coriolis and advection terms did not change much during

342 EN (magenta and green lines in Fig. 11c), but they are relatively important for the budget in mean climatological 343 conditions (magenta and green lines in Fig. 11b and 12b). Note that the pressure gradient was strong at surface 344 and in upper layers during EN. Air temperature decreased between the surface and $1600 \mathrm{~m}$, showing no 345 temperature inversion in this period (austral summer) in mean climatological or EN conditions (Fig. 11d). 
346 This time period is contrasted with the period July-August 1997, during which the surface wind anomalies were

347 weak (Figs. 5a and 12a) in spite of SST anomalies of the same order $\left(\sim 4^{\circ} \mathrm{C}\right)$ as during November 1997-April

3481998 (Fig. 5b). Between the surface and $800 \mathrm{~m}$ the wind speed decreased with respect to mean climatological

349 conditions, and did not change in the upper layers $(800-1600 \mathrm{~m})$. The wind shear decreased between the surface

350 and $400 \mathrm{~m}$ (black line in Fig. 12a), mainly due to the velocity decrease between $300-400 \mathrm{~m}(\sim 10 \%)$ and a

351 virtually unchanged velocity at surface. Mixing coefficient $\left(\mathrm{K}_{\mathrm{z}}\right)$ increased by almost $70 \%$ in this period, reaching

352 a maximum of $\sim 74 \mathrm{~m}^{2} \cdot \mathrm{s}^{-1}$ at $250 \mathrm{~m}\left(\sim 45 \mathrm{~m}^{2} \mathrm{~s}^{-1}\right.$ in climatological conditions at $220 \mathrm{~m}$, blue line in Fig. 12a). The

353 changes in wind shear and turbulent vertical mixing $\left(\mathrm{K}_{\mathrm{z}}\right)$ in this period counteracted such that the momentum

354 vertical mixing term did not change significantly (blue line in fig 12c), thus compensation. The wind decrease

355 below $\sim 600 \mathrm{~m}$ was likely driven by advection, which decreased below $500 \mathrm{~m}$ (green line in Fig. 12c) whereas the

356 pressure gradient change remained positive (red line in Fig. 12c). On the other hand, the pressure gradient

357 vertical shear between the surface and $\sim 600 \mathrm{~m}$ (Fig. 12c) was stronger than in November 1997-February 1998

358 period (Fig. 11c). Note also the well-marked temperature inversion in July-August 1997 (Fig. 12d). The effect of

359 this particular vertical structure on the pressure gradient will be discussed below (Sect. 4.2).

\subsection{Impacts of large scale atmospheric forcing and local SST forcing}

362 In this subsection, we analyzed the model sensitivity experiments to study the respective roles of the large scale

363 atmospheric signal (BRY EN experiment, forced by 1997-1998 EN boundary conditions and neutral SST forcing

364 from the years 1994-1995) and of the SST local forcing (SST-EN experiment, forced by EN SST forcing and

365 1994-1995 neutral boundary conditions, see section 2.5) in driving the EN wind anomalies.

367 Figure 13a displays the alongshore surface wind anomalies (averaged in the coastal band between $7^{\circ} \mathrm{S}$ and $15^{\circ} \mathrm{S}$ )

368 for the CRTL, BRY-EN, SST-EN experiments. The large scale signal (BRY-EN simulation) during EN induced

369 strong negative wind anomalies $\left(\sim-1 \mathrm{~m} \mathrm{~s}^{-1}\right)$ between March and September 1997, and moderate $\left(<1 \mathrm{~m} \mathrm{~s}^{-1}\right)$

370 positive anomalies between October 1997 and March 1998. In contrast, the model forced by the 1997-98 SST

371 forcing (SST-EN) simulated persistent positive wind anomalies between May 97 and August 97 (reaching 1 m

$372 \mathrm{~s}^{-1}$ in August 97) and between November 1997 and May 1998 (peaking at $\sim 1.5 \mathrm{~m} \mathrm{~s}^{-1}$ in January-February 98).

373 There was a slightly negative anomaly in September 1997, which coincided with the slight decrease of SST

374 anomaly in September-October 1997 (Fig. 5b). Note that the wind anomaly was negligible in CRTL in Jul-Aug 
375 1997, in spite of a strong SST anomaly ( 3-4 ${ }^{\circ} \mathrm{C}$, Fig. 5b). This can be explained by the large scale signal, which 376 forced a decrease of the equatorward wind (negative anomalies of $\sim-1 \mathrm{~m} \mathrm{~s}^{-1}$ in July-September 1997 in BRY-

377 EN) which compensated the wind increase $\left(\sim 0.5-1 \mathrm{~m} \mathrm{~s}^{-1}\right.$ in SST-EN) forced by the anomalously warm SST.

379 In the first warm period (July-August 1997), the intensification of the wind driven by the SST forcing (SST-EN

380 experiment) was compensated by the large scale signal (BRY-EN) not only at the surface but also as high as

$3811400 \mathrm{~m}$ (Fig. 13b). During the second period (November 1997-February 1998), boundary conditions (BRY-EN

382 simulation) did not have a strong effect. The wind was modified very little in the vertical with respect to

383 climatological conditions. The wind intensification below $200 \mathrm{~m}$ was fully forced by the anomalous SST (Fig. 384 13c).

386 Thus, the BRY-EN experiment showed that the large-scale atmospheric signal propagating into the Peru region 387 through the open boundaries could mitigate (or enhance) the coastal wind anomalies during EN. The SPA center 388 was located around its mean climatological position into both periods (red lines in Figs 14 a,b). However, during 389 March-September 1997, the SPA was weaker (-1-2 hPa anomaly) than in mean climatological conditions 390 (Fig.14a). This weakening should produce negative anomalies for the surface atmospheric pressure off Peru, 391 which likely contributed to a decrease of the alongshore wind off Peru in the BRY-EN simulation. Indeed, the 392 maximum surface pressure in the SPA was well correlated (0.67) with BRY-EN wind anomalies during the EN 393 period. In contrast with the March-September 1997 period, the SPA was slightly more intense in October 1997394 March 1998 (Fig. 14b) and September 98 (not shown), favoring an intensification of the coastal wind during 395 these time periods due to SST forcing (Fig.13a).

\section{4. Discussion and conclusions}

\section{4.1 Summary}

399 A regional atmospheric model was used to investigate the physical processes driving the wind intensification off

400 the Peru coast during the 1997-1998 EN event. As anomalously warm waters accumulated near the coast, the 401 equatorward coastal wind increased by $\sim 1-1.5 \mathrm{~m} \mathrm{~s}^{-1}$ during 5-6 months (up to $40 \%$ increase with respect to the 402 climatological mean over the 1994-2000 period). Simulated surface wind anomalies during EN were in good 403 agreement with observed wind anomalies. A momentum balance analysis showed that the coastal wind 
404 intensification was mainly driven by the enhancement of the alongshore pressure gradient. Vertical mixing

405 tended to counterbalance the alongshore pressure gradient, leading to a quasi-equilibrium between the

406 alongshore pressure gradient and the frictional force, consistently with previous modeling studies in the region

407 (Muñoz and Garreaud, 2005; Belmadani et al., 2013). The enhancement of the alongshore pressure gradient

408 occured because the atmospheric pressure decreased more north $\left(\sim 6^{\circ} \mathrm{S}\right)$ than south $\left(\sim 14^{\circ} \mathrm{S}\right)$, in association with

409 the larger increase of SST, air temperature and humidity off northern Peru. Surface warming induced an increase

410 of the height of the PBL of up to two and half times and of the vertical turbulent mixing coefficient

$411\left(\mathrm{~K}_{\mathrm{z}}=\tau /(\mathrm{dV} / \mathrm{dz})\right)$ of up to three times their values in mean climatological conditions. However vertical mixing of

412 momentum $(\mathrm{d} \tau / \mathrm{dz})$ remained negative and was stronger (in absolute value) during EN that in mean

413 climatological conditions, thus did not accelerate the equatorward wind.

\section{4.2 The back-pressure effect during EN}

416 The alongshore pressure gradient change was strong at surface and its vertical structure varied during the EN

417 period: the pressure gradient change was strong between the surface and $\sim 1000 \mathrm{~m}$ when there was no temperature

418 inversion (e.g. in November 1997-February 1998; Figs. 11b,c). In contrast, it became negligible above 600m in

419 the presence of a marked temperature inversion (e.g. in July-August 1997; Figs. 12b,c). Hashizume et al. (2002)

420 showed that the so-called "back-pressure effect", a mechanism compensating the surface pressure gradients, was

421 strong in the case of a marked temperature inversion above the PBL. Oerder et al. (2016) found that this effect

422 reduced significantly the intensity of the surface pressure gradient above mesoscale SST positive anomalies in

423 the Peru region. This is also likely the case in the Peru coastal region in our simulation during the period July-

424 August 1997 (Fig. 12c). Note that temperature inversion is related to the strong atmospheric subsidence in the 425 region led by the SPA (e.g. Haraguchi 1968).

426 In conclusion, it is likely that two conditions, a SST anomaly alongshore gradient and a weak (or absent)

427 temperature vertical inversion would be necessary to drive a strong surface wind anomaly in the coastal region.

428 The SST gradient drives the pressure gradient, and the weak temperature inversion allows shallow convection to 429 develop without triggering any "back-pressure effect".

\section{$431 \quad 4.3$ Land-sea thermal contrast}

432 Bakun et al. (2010) suggested that the increase of humidity over coastal land during EN could enhance the local 
433 greenhouse heating effect, thus increasing land temperature more than SST. This thermal contrast would lead to

434 the presence of lighter air over land than over sea, an intensification of the cross-shore pressure gradient and

435 associated alongshore geostrophic wind. Similarly, Enfield (1981) suggested that a land-sea thermal contrast may

436 occur due to an increase of downward solar radiation over land, which would be due to a reduction of cloudiness

437 during EN. As Bakun et al. (2010) and Enfield (1981) suggested, humidity and incoming solar radiation

438 increased over land during EN in our simulations (green and red lines respectively; Fig. 15). However, this

439 increase in humidity and short wave radiation reaching the land surface did not support a strengthened land-sea

440 thermal contrast. Indeed, the simulated land-sea contrast, which was positive (i.e. air temperature was higher

441 over land than over sea) in mean climatological conditions (not shown), decreased by 100\% during EN (blue

442 line in Fig.15) as the air temperature over sea increased much more than the air temperature over land (not

443 shown). Note that a clear relation between land-sea thermal contrast and alongshore winds off Peru has not been

444 demonstrated in previous studies. Using a set of GCM simulations with a spatial resolution of $\sim 50 \mathrm{~km}$ in the

445 Peru-Chile region, Belmadani et al. (2013) found that the land-sea thermal contrast (dT/dx) increased off Peru in

446 scenarios of climate change: at $8^{\circ} \mathrm{S}$, dT/dx was $\sim 4.510^{-2} \mathrm{~K} \mathrm{~km}^{-1}$ in preindustrial climate conditions, and reached

$447 \sim 6.510^{-2} \mathrm{~K} \mathrm{~km}^{-1}$ in $4 \mathrm{xCO} 2$ climate conditions, thus increased by $\sim 40 \%$ (see Figure $8 \mathrm{c}$ in Belmadani et al. 2013).

448 In spite of this strong increase, the alongshore wind decreased moderately $(\sim 10 \%)$ off Peru. This reduction was

449 driven by a decrease of the alongshore pressure gradient associated with a poleward displacement of the SPA in a

450 warmer climate (Belmadani et al. 2013 and references herein). This and our results suggest that an increase of

451 the land-sea thermal gradient may not play a strong dynamical role for the alongshore wind, at least for the range

452 of horizontal resolution ( $\sim 25 \mathrm{~km}$ in the present study and $\sim 50 \mathrm{~km}$ in Belmadani et al. 2013) explored in our

453 model simulations. Note that these resolutions do not allow to represent the coastal terrain located between the

454 Andes and the ocean with more than a few grid points.

456 In addition, our model simulated poorly the mean downward shortwave radiation associated with the cloud 457 cover, a well-known problem in models of the Southeast Pacific lower troposphere (e.g. Wyant et al. 2010).

458 Despite this bias, the model reproduced reasonably well the surface air temperature distribution and, more 459 importantly for the purpose of the present study, the air temperature anomalies at surface during EN, in 460 agreement with reanalysis data (not shown). The modelled air temperature increased more over sea than over the 461 land during EN associated with the strong SST warming, thus reducing the land-sea thermal contrast. However, 
462 the land-sea thermal contrast may impact the wind at scales smaller than those resolved by the present model

463 (e.g. Enfield, 1981). This process remains to be investigated using higher resolution model experiments in future

464 work.

466 4.4 Dynamical processes during other EN events

467 Due to the model computational cost, our simulations were performed for a relatively short time period (1994-

468 2000) including only one EN event. In order to evaluate if the same dynamical processes were active during 469 other events, we performed similar diagnostics using the ERA-Interim reanalysis data over the period 1979-

470 2016. This data has a lower spatial resolution $(\sim 80 \mathrm{~km})$ than our regional model, but it can give hints of the 471 processes at stake during EN events. The wind anomaly (in a coastal band of $\sim 160 \mathrm{~km}$ and between $7^{\circ} \mathrm{S}$ and $\left.47215^{\circ} \mathrm{S}\right)$ for the $1997-98 \mathrm{EN}$ was $\sim 0.6-0.8 \mathrm{~m} \mathrm{~s}^{-1}$, less than in our model $\left(\sim 1.0-1.2 \mathrm{~m} \mathrm{~s}^{-1}\right.$ for an average over $6 \mathrm{WRF}$ 473 grid points). We found relatively strong wind anomalies during most EN events, in particular in $1982-83(\sim 0.8 \mathrm{~m}$ $\left.474 \mathrm{~s}^{-1}\right), 1987-88\left(\sim 1 \mathrm{~m} \mathrm{~s}^{-1}\right), 1992-93\left(0.7 \mathrm{~m} \mathrm{~s}^{-1}\right), 2015-16\left(0.8 \mathrm{~m} \mathrm{~s}^{-1}\right)$ (Fig. 16). In agreement with our analysis, 475 these four events were associated with positive alongshore SST gradient anomalies (e.g. $\sim 0.1510^{-} 2{ }^{\circ} \mathrm{C} \mathrm{km}{ }^{-1} \mathrm{in}$ 476 1982-83). There were also EN events with relatively weak wind anomalies (i.e. 2002-2003). Note that strong 477 SST gradient anomalies occurred during relatively short time periods in 1993, 2002 and 2008, and were not 478 associated with positive wind anomalies. We may conjecture that other processes such as a compensation by the 479 large scale forcing through a modification of the SPA or the presence of temperature inversion with a back480 pressure effect may be active during these periods.

\section{$482 \quad 4.5$ Local air-sea coupled processes during EN}

483 Local air-sea coupled interactions not investigated in the present study may also play a role during EN. First, the 484 increase of humidity in the north of Peru leads to intense precipitation on land and over the nearshore ocean 485 (Takahashi, 2004), which may enhance the ocean surface stratification. This may mitigate wind-driven oceanic 486 vertical mixing in the north and thus help maintaining the anomalous alongshore SST gradient driving the 487 coastal wind. On the other hand, the stronger coastal wind (Figs 1b and 5a), SST (Fig.5b) and humidity (Fig.8c) 488 anomalies in the north would increase evaporation and thus cool the ocean more efficiently than further south. 489 This effect may mitigate the SST gradient and thus reduce the wind anomaly. Studying such feedbacks, which 490 were not taken into account in our forced atmospheric model framework, is beyond the scope of the present 
491 study. These questions, which can be addressed using a regional high resolution, ocean-atmosphere coupled

492 model (e.g. Oerder at al. 2016), will be the purpose of future studies.

494 5. Acknowledgments

495 This research is part of A. Chamorro's $\mathrm{PhD}$ thesis, funded by the fellowship from

496 CIENCIACTIVA/CONCYTEC-PERU at the University Pierre and Marie CURIE of France. It is also part of the

497 IDB project PE-G1001(Adaptation to Climate Change of the Fishery Sector and Marine-Coastal Ecosystem),

498 and it is a contribution to the cooperative agreement between the Instituto del Mar del Peru (IMARPE) and the

499 Institut de Recherche pour le Developpement (IRD) and the LMI DISCOH. The simulations were performed on

500 the supercomputer Curie from the GENCI at the CEA (projects 2011040542, 2012061047 and 2014102286).

501 Francois Pinsard is acknowledged for her help in the making of lateral boundary forcing for the regional

502 atmospheric model. Francis Codron and Clémentine Junquas are acknowledged for useful discussions.

503

504 6. References

505 Bakun A, Field D, Renondo-Rodriguez A, Weeks SJ (2010) Greenhouse gas, upwelling favourable winds, and 506 the future of upwelling systems. Glob Chang Biol 16:1213-1228

507

508 Belmadani A, Echevin V, Codron F, Takahashi K, Junquas C (2014) What dynamics drive future wind scenarios

509 for coastal upwelling off Peru and Chile? Clim Dyn 43: 1893-1914. doi:10.1007/s00382-013-2015-2

511 Bentamy A, Grodsky SA, Katsaros K, Mestas-Nuñez AM, Blanke B, Desbiolles F (2013) Improvement in air-sea

512 flux estimates derivedfrom satellite observations. Int $\mathbf{J}$ Remote Sens 34(14):5243-5261.

513 doi:10.1080/01431161.2013.787502

514

515 Bjerknes J (1966) Survey of El Niño 1957-58 in its relation to tropical Pacific meteorology. Inter-American

516 Tropical Tuna Commission Bulletin 12(2):, pp 1-62

518 Boé J, Hall A, Colas F, McWilliams JC, Qu X, Kurian J, Kapnick SB (2011) What shapes mesoscale wind

519 anomalies in coastal upwelling zones? Clim Dyn 36(11-12):2037-2049 
521 Capet XJ, Marchesiello P., McWilliams JC (2004) Upwelling response to coastal wind profiles. Geophys Res

522 Lett 31, L13311. doi:10.1029/2004GL020123

523

524 Carr M-E., Strub PT, Thomas AC, Blanco JL (2002) Evolution of 1996 - 1999 La Nina and El Nino conditions

525 off the western coast of South America: A remote sensing perspective. J Geophys Res 107(C12), 3236.

526 doi:10.1029/2001JC001183

527

528 CERSAT (2002a) Mean wind fields (MWF product) user manual volume 1: ERS-1, ERS-2 \& NSCAT. Rep C2-

529 MUT-W-05-IF. CERSAT-IFREMER, Brest

530

531 CERSAT (2002b) Mean wind fields (MWF product) user manual volume 1: QuikSCAT. Rep C2-MUT-W-04-IF.

532 CERSAT-IFR- EMER, Brest

533

534 Chavez FP, Barber RT (1987) An estimate of new production in the equatorial Pacific. Deep-Sea Research 535 34(7):1229-1243. doi.org/10.1016/0198-0149(87)90073-2

536

537 Chavez FP, Bertrand A, Guevara-Carrasco R, Soler P, Csirke P (2008) The northern Humboldt Current System:

538 Brief history, present status and a view towards the future. Prog Oceanogr 79(2-4):95-105.

539 doi:10.1016/j.pocean.2008.10.012

540

541 Chavez FP, Messié M (2009) A comparison of eastern boundary upwelling ecosystems. Prog Oceanogr 83(1):8054296.

544 Chen F, Dudhia J (2001) Coupling an advanced land surface hydrology model with the penn state-NCAR MM5

545 modeling system. Part ii: Preliminary model validation. Mon Weather Rev 129(4):587-604. doi:10.1175/1520-

$546 \quad 0493(2001) 129<0587: \mathrm{CAA}$ LSH $>2.0 . \mathrm{CO} ; 2$

548 Colas F, Capet X, McWilliams JC, Shchepetkin A (2008) 1997-98 El Niño off Peru: A numerical study. Prog 
551 Dee, D.P. et al (2011) The ERA-Interim reanalysis: configuration and performance of the data assimilation system. Q J R Meteorol Soc A 137:553-597. doi:10.1002/qj.828

554 Dudhia J (1989) Numerical study of convection observed during the winter monsoon experiment using a 555 mesoscale two-dimensional model. J Atmos Sci 46:3077-3107. doi:10.1175/1520-0469(1989)046<3077: 556 NSOCOD>2.0.CO;2.

558 Enfield DB (1981) Thermally-driven wind variability in the planetary boundary layer above Lima, Peru. J

559 Geophys Res 86(C3):2005-2016

561 Estrade P, Marchesiello P, Colin de Verdiere A, Roy C (2008) Cross-shelf structure of coastal upwelling: A two-

562 dimensional expansion of Ekman's theory and a mechanism for innershelf upwelling shut down. J Mar Res 563 66:589-616.

565 Haraguchi PY (1968) Inversions over the tropical eastern Pacific ocean. Mon Weather Rev 96:177-185

567 Hashizume H, Xie SP, Fujiwara M, Tanimoto TWY (2002) Direct observations of atmospheric boundary layer 568 response to SST variations associated with tropical instability waves over the Eastern Equatorial Pacific. J Clim 569 15:3379-3393. doi:10.1175/1520-0442(2002)015<3379:DOOABL>2.0.CO;2

571 Hong S, Lim J (2006) The WRF single-moment 6-class microphysics scheme (WSM6). J Korean Meteorol Soc $572 \quad 42(2): 129-151$

574 Janjic ZI (1994) The step-mountain eta coordinate model: further developments of the convection, viscous 575 sublayer, and turbulence closure schemes. Mon Wea Rev 122:927-945. doi:10.1175/1520576 0493(1994)122<0927:TSMECM>2.0.CO;2 
578 Kessler WS (2006) The circulation of the eastern tropical Pacific: A review. Prog Oceanogr 69(2):181-217

580 Lindzen R, Nigam S (1987) On the role of sea surface tem- perature gradients in forcing low level winds and

581 convergence in the Tropics. J Atmos Sci 44:2418-2436. doi:10.1175/1520-

$582 \quad 0469(1987) 044<2418:$ OTROSS $>2.0 . C O ; 2$

583

584 Nakanishi M, Niino H (2009) Development of an improved turbulence closure model for the atmospheric

585 boundary layer. J Meteorol Soc Jpn 87:895-912. doi:10.2151/jmsj.87.895

586

587 Madec G (2008) NEMO ocean engine. Note du Pole de modélisation,

588 Institut Pierre-Simon Laplace (IPSL) 27. ISSN No. 1288-1619.

590 McPhaden MJ (1999) Genesis and evolution of the 1997-98 El Niño. Science 283:950-954.

592 Mlawer E, Taubman S, Brown P, Iacono M, Clough S (1997) Radiative transfer for inhomogeneous atmosphere:

593 RRTM, a validated correlated-k model for the long-wave. J Geophys Res 102:16,663-16,682.

594 doi:10.1029/97JD00237

595

596 Muñoz RC, Garreaud RD (2005) Dynamics of the low-level jet off the west coast of subtropical South America.

597 Mon Wea Rev 133:3661-3677. doi:10.1175/MWR3074.1

598

599 Oerder V, Colas F, Echevin V, Masson S, Hourdin C, Jullien S, Gurvan M, Lemarié F (2016) Mesoscale SST-

600 wind stress coupling in the Peru-Chile current system: Which mechanisms drive its seasonal variability? Clim

601 Dyn (2016) 47:2309. doi:10.1007/s00382-015-2965-7

602

603 Penven P, Echevin V, Pasapera J, Colas F, Tam J (2005) Average circulation, seasonal cycle, and mesoscale

604 dynamics of the Peru current system: Amodeling approach. J Geophys Res 110, C10021.

605 doi:10.1029/2005JC002945

606 
607 Picaut J, Hackert E, Busalacchi A, Murtugudde R , Lagerloef GSE (2002), Mechanisms of the 1997-1998 El 608 Niño-La Niña, as inferred from space-based observations. J Geophys Res Oceans 107 (C5). doi: $60910.1029 / 2001 \mathrm{JC} 000850$.

610

611 Rahn DA (2012) Influence of large scale oscillations on upwelling-favorable coastal wind off central Chile. J

612 Geophys Res 117, D19114. doi:10.1029/2012JD018016

613

614 Renault L, Hall H, McWilliams JC (2016) Orographic shaping of USWest Coast wind profiles during the 615 upwelling season. Clim Dynam 46:273-289. doi:10.1007/s00382-015-2583-4

616

617 Reynolds RW, Smith TM, Liu C, Chelton DB, Casey KS, Schlax MG (2007) Daily high-resolution-blended 618 analyses for sea surface temperature. J Climate 20:5473-5496. doi:10.1175/2007JCLI1824.1.

620 Skamarock W, Klemp J (2008) A time-split nonhydrostatic atmos- pheric model for weather research and

621 forecasting applications. J Comp Phys 227:3465-3485. doi:10.1016/j.jcp.2007.01.037

622

623 Strub PT, J Mesías, V Montecino, J Rutllant \& S Salinas. 1998. Coastal ocean circulation off Western South

624 America. In: Robinson AR \& KH Brink (eds). The global coastal ocean: Regional studies and syntheses. The Sea 625 11: 273-314. John Wiley, New York.

627 Takahashi K (2004) The atmospheric circulation associated with extreme rainfall events in Piura, Peru, during 628 the 1997-1998 and 2002 El Niño events. Ann Geophys 22:3917-3926. doi:10.5194/angeo-22-3917-2004

630 Takahashi K, Battisti DS (2007) Processes Controlling the Mean Tropical Pacific Precipitation Pattern. Part I:

631 The Andes and the Eastern Pacific ITCZ. Journal of Climate 20:3434-3451. doi: 10.1175/JCLI4198.1

633 Wallace JM, Hobbs PV (2006) Atmospheric Science: A Introductory Survey. 2nd ed. Academic Press, pp 483 634

635 Wallace JM, Mitchell T, Deser C (1989) The influence of sea surface temperature on surface wind in the Eastern 
636 Equatorial Pacific: seasonal and interannual variability. J Clim 2:1492-1499. doi:10.1175/1520-

637 0442(1989)002<1492:TIOSST>2.0.CO;2

638

639 Wyant MC et al (2010) The PreVOCA experiment: modeling the lower troposphere in the Southeast Pacific.

640 Atmos Chem Phys 10:4757-4774. doi:10.5194/acp-10-4757-2010

641

642 Wyrtki K (1975). El Niño: the dynamic response of the equatorial Pacific to atmospheric forcing. Journal of

643 Physical Oceanography 5:572-584

644

645 Xue H, Wang Y, Xie SP (2004) Effects of the andes on eastern pacific climate: a regional atmospheric model

646 study. J Clim 17:587-602

647

648 Zeng X, Beljaars A (2005) A prognostic scheme of sea surface skin temperature for modeling and data

649 assimilation. Geophysical Research Letters 31:L14605. doi: 10.1029/2005GL023030

650

651 Zuta S, Guillén O (1970) Oceanografía de las aguas costeras del Perú. Boletin Instituto del Mar del Perú 2: 157-

652324

653

654 7. Tables

655 Table 1. Parameterizations used in WRF model for the simulations.

656

657

\begin{tabular}{|l|l|l|}
\hline \multicolumn{1}{|c|}{ Processes } & \multicolumn{1}{c|}{ Scheme } & \multicolumn{1}{c|}{ Reference } \\
\hline Shortwave Radiation & Dudhia scheme & Mlawer et al. (1997) \\
\hline Longwave Radiation & RRTM scheme & Hong and Lim (2006) \\
\hline Microphysics & $\begin{array}{l}\text { WRF Single-Moment 6-class } \\
\text { scheme }\end{array}$ & Janjic (1994) \\
\hline Cumulus & Betts-Miller-Janjic scheme & Nakanishi and Niino (2009) \\
\hline Surface Layer & MYNN surface layer & Chen and Dudhia (2001) \\
\hline Land Surface & Noah Land Surface Model & Nakanishi and Niino (2009) \\
\hline Planetary Boundary Layer & MYNN Level 2.5 PBL & \\
\hline
\end{tabular}

658 


\section{8. Figure captions}

660 Figure 1. a) ERS wind anomalies (in $\mathrm{m} \mathrm{s}^{-1}$ ) off Peru and Northern Chile during El Niño conditions in November-

661 February 1997/1998. Arrows mark the direction of the monthly wind anomalies. b) Time-latitude diagram of

662 ERS alongshore monthly wind anomalies off the Peru coast. The wind average was computed within a $100 \mathrm{~km}-$

663 wide coastal band and a 3-month running mean was applied. Positive values indicate equatorward wind 664 anomalies.

665

666 Figure 2. South East Pacific model domain and Peru nested domain used in the WRF simulations. Color shading

667 indicates model topography (in meters) above sea level for the small domain.

669 Figure 3. Mean surface wind (in $\mathrm{m} \mathrm{s}^{-1}$ ) in 2000 from a) ERS satellite, b) WRF model and c) QSCAT satellite.

670 Mean annual cycle of the alongshore wind (averaged in a 100-km-wide coastal domain) from d) ERS and e)

671 WRF over the period 1994-2000, and from f) QSCAT over the period 2000-2008.

673 Figure 4. Vertical structure of the mean meridional wind (shading, in $\mathrm{m} \mathrm{s}^{-1}$ ) and air temperature (black contours, in ${ }^{\circ} \mathrm{C}$ ) at $15^{\circ} \mathrm{S}$ from a) ERA-Interim and b) WRF

675 model. Data was averaged for the 1994-2000 period.

677 Figure 5. a) Mean surface wind anomalies (in $\mathrm{m} \mathrm{s}^{-1}$ ) from WRF (over November 1997-February 1998) and b)

678 time-latitude diagram of WRF alongshore wind anomalies. c) Mean sea surface temperature (SST) anomalies 679 (in ${ }^{\circ} \mathrm{C}$ ) from OISST (over the same time period in a)) and d) time-latitude diagram of alongshore SST 680 anomalies

682 Figure 6. Anomalies of the meridional component of the surface forces contribution (in $\mathrm{m} \mathrm{s}^{-1}$ ) during El Niño 683 1997/1998: a) advection (V-ADV'), b) vertical turbulent mixing (V-MIX'), c) pressure gradient (V-PGF'), and d)

684 Coriolis force (V-COR'). Anomalies were computed with respect to a climatology over 1994-2000 and averaged 685 over November 1997-February 1998. e) Time series of the monthly anomalies of the alongshore component of 686 the surface forces contribution in 1997-1998 (in m.s ${ }^{-1}$, with scale defined by the left-hand side y axis). The 687 forces were averaged in a $100-\mathrm{km}$ coastal band between $7^{\circ} \mathrm{S}$ and $15^{\circ} \mathrm{S}$. Gray, black and black-dashed lines 
688 indicate tendency (the month to month wind anomaly difference), the sum of all terms and wind anomaly

689 (relative to climatology), respectively (in $\mathrm{m} . \mathrm{s}^{-}{ }^{1}$, with scale defined by the right-hand side y axis).

691 Figure 7. a) Alongshore anomalies of pressure gradient (in $\mathrm{m} \mathrm{s}^{-1}$, shading) and coastal wind (in $\mathrm{m} \mathrm{s}^{-1}$, black

692 contours) between the equator and $20^{\circ} \mathrm{S}$. b) Latitudinal variation of the correlation between alongshore pressure 693 gradient anomalies and alongshore coastal wind anomalies.

695 Figure 8. Alongshore vertical sections of the mean monthly anomalies (during November 1997-February 1998) 696 of a) virtual temperature (in ${ }^{\circ} \mathrm{C}$ ) and b) temperature and c) humidity contributions (in ${ }^{\circ} \mathrm{C}$ ) to the virtual 697 temperature anomaly. Note the different scales for temperature and humidity contribution. d) Vertical profiles of 698 humidity in the northern coastal region $\left(4^{\circ} \mathrm{S}-8^{\circ} \mathrm{S}\right)$ during November 1997-January 1998 (full line) and mean 699 climatological conditions (dashed line).

701 Figure 9: Time evolution of alongshore SST gradient (in ${ }^{\circ} \mathrm{C} / 25 \mathrm{~km}$, positive equatorward, red line) and wind (in $702 \mathrm{~m} \mathrm{~s}^{-1}$, black line) anomalies. Anomalies were smoothed using a 3-month running mean, and averaged between $7037^{\circ} \mathrm{S}$ and $15^{\circ} \mathrm{S}$ and within $100 \mathrm{~km}$ from the coast.

705 Figure 10. Mean Planetary Boundary Layer Height (in meters, PBLH) off Peru. PBLH was averaged between $7067^{\circ} \mathrm{S}$ and $15^{\circ} \mathrm{S}$ and within $100 \mathrm{~km}$ from the coast. Red line marks PBLH during 1997-1998, and black dashed line 707 the climatology. Error bars indicate standard deviation from the mean climatological values.

709 Figure 11. Vertical profiles of a) alongshore wind (in $\mathrm{m} \mathrm{s}^{-1}$ ), b) alongshore forces in mean climatological 710 conditions (in $\mathrm{m} \mathrm{s}^{-1}$ ), c) anomalies of alongshore forces in Niño conditions (in $\mathrm{m} \mathrm{s}^{-1}$ ) and d) air temperature (in

$\left.71{ }^{\circ} \mathrm{C}\right)$. Averages were computed over November 1997 -February 1998 , between $7^{\circ} \mathrm{S}$ and $15^{\circ} \mathrm{S}$, and within $100 \mathrm{~km}$

712 from the coast. Full and dashed lines in a) and c) correspond to El Niño and mean climatological conditions, 713 respectively.

715 Figure 12. Same as Figure 11 but for the period July-August 1997. 
717 Figure 13: a) Time series of coastal alongshore wind anomalies (in $\mathrm{m} \mathrm{s}^{-1}$ ) from CRTL (black line), SST-EN (red 718 line), BRY-EN (blue line) experiments. Mean alongshore wind profiles (in m s${ }^{-1}$ ) in b) July-August 1997 and c)

719 November 1997-February 1998. Black-dashed, black, red and blue lines mark the climatological (CLIM) ,CRTL,

720 SST-EN and BRY-EN profiles, respectively.

722 Figure 14. Mean (red contours) and anomalous (shading) sea level pressure (in hPa) during a) March-September 7231997 and b) October 1997-March 1998. White contours mark pressure climatological values (1994-2000).

725 Figure 15 . Anomalies of air humidity at 2 meters (in $\mathrm{g} \mathrm{kg-}^{-1}$, green line), downward shortwave radiation at sea 726 surface (in $\mathrm{W} \mathrm{m}^{-2}$, red line) and land-sea air temperature gradient at 2 meters (in $10^{-2}{ }^{\circ} \mathrm{C} \mathrm{km}$, blue line). 727 Anomalies of air humidity and shortwave radiation were taken at the model land grid points closest to sea.

728 Temperature gradient was computed as the difference between the model land grid point closest to sea and the 729 sea grid point closest to land at each latitude. All variables were averaged between $7^{\circ} \mathrm{S}$ and $15^{\circ} \mathrm{S}$.

731 Figure 16. Time evolution of alongshore SST gradient (in ${ }^{\circ} \mathrm{C} / 80 \mathrm{~km}$, positive equatorward, red line) and 732 alongshore wind (in $\mathrm{m} \mathrm{s}^{-1}$, black line) anomalies for ERA-Interim reanalysis over 1979-2016. Anomalies were 733 averaged in a $160-\mathrm{km}$-wide coastal band and between $7^{\circ} \mathrm{S}$ and $15^{\circ} \mathrm{S}$. Grey vertical bands indicate El Niño 734 periods. 
a)

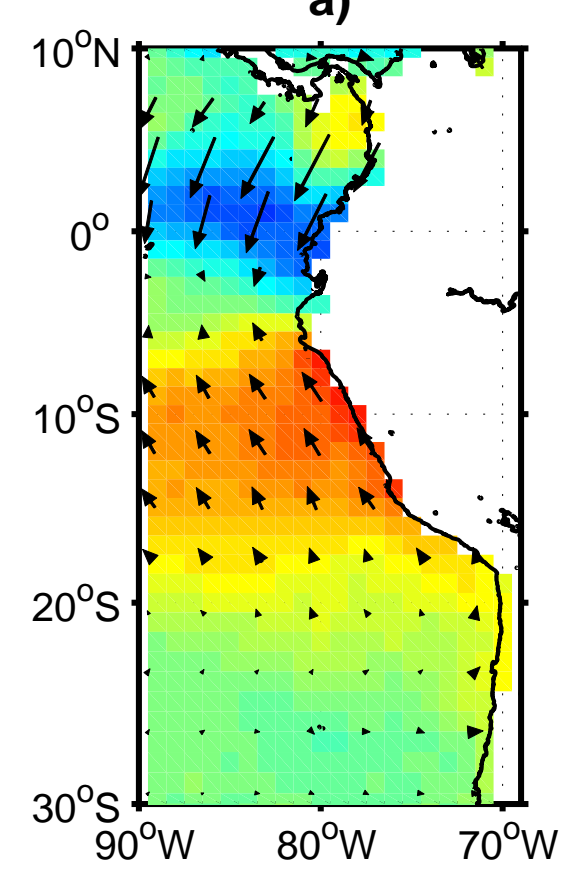

b)

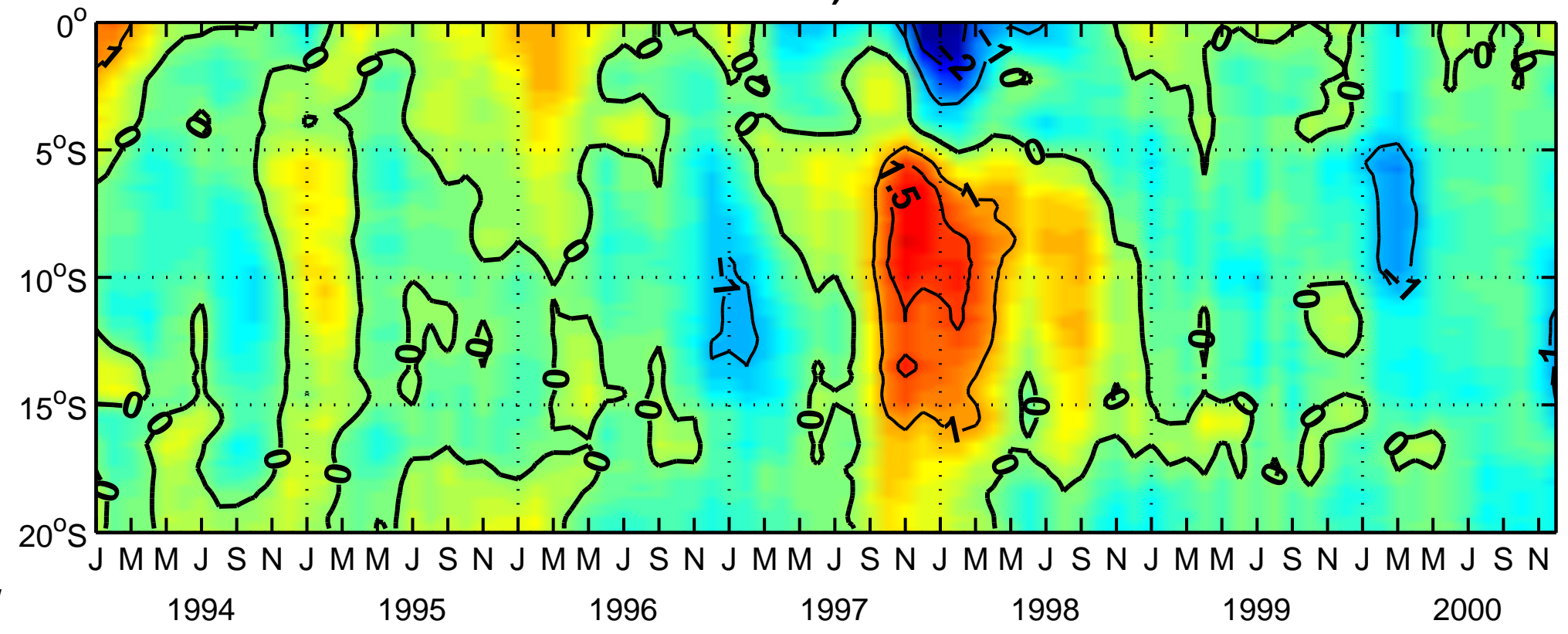

2 


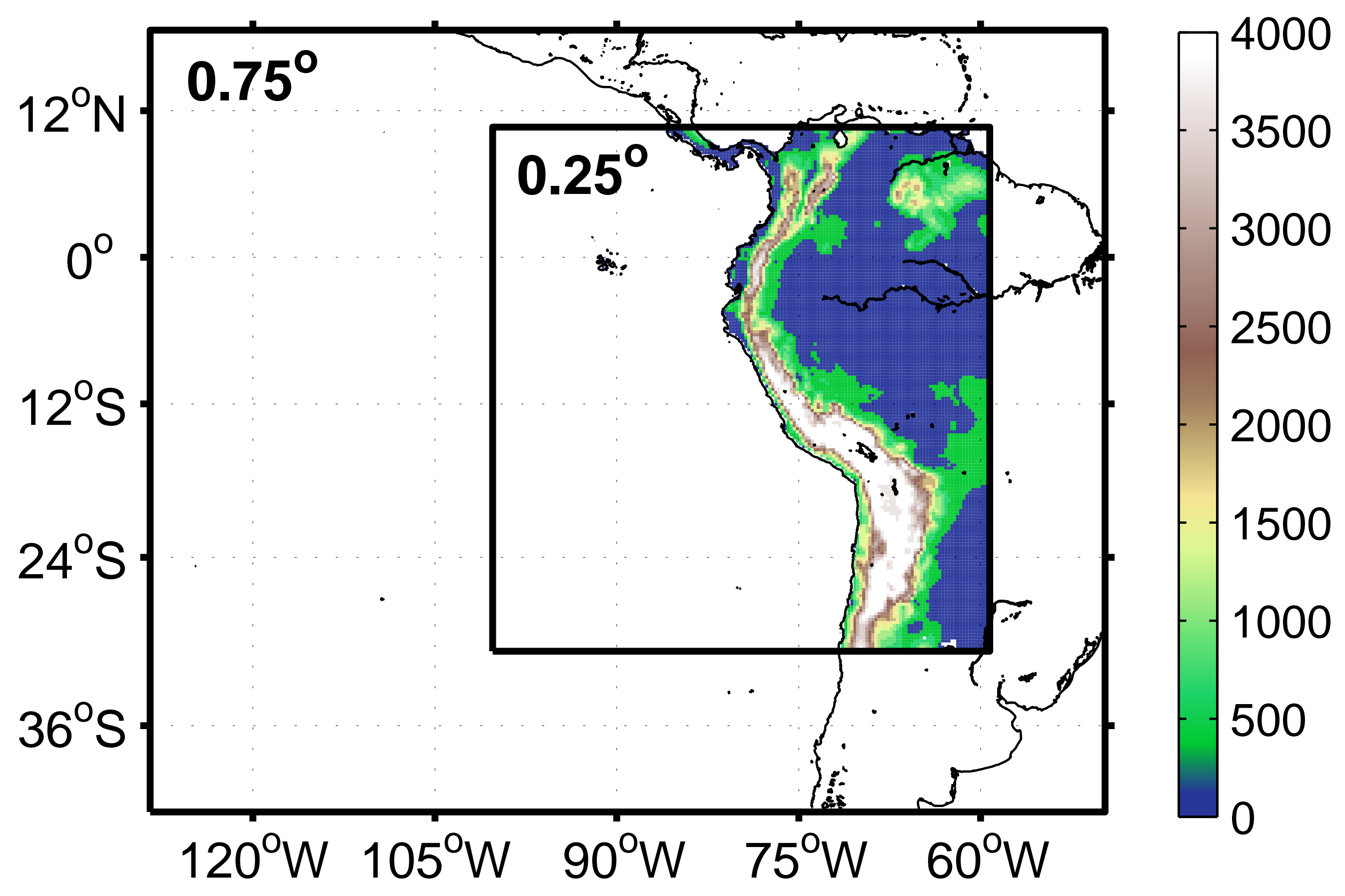


a)

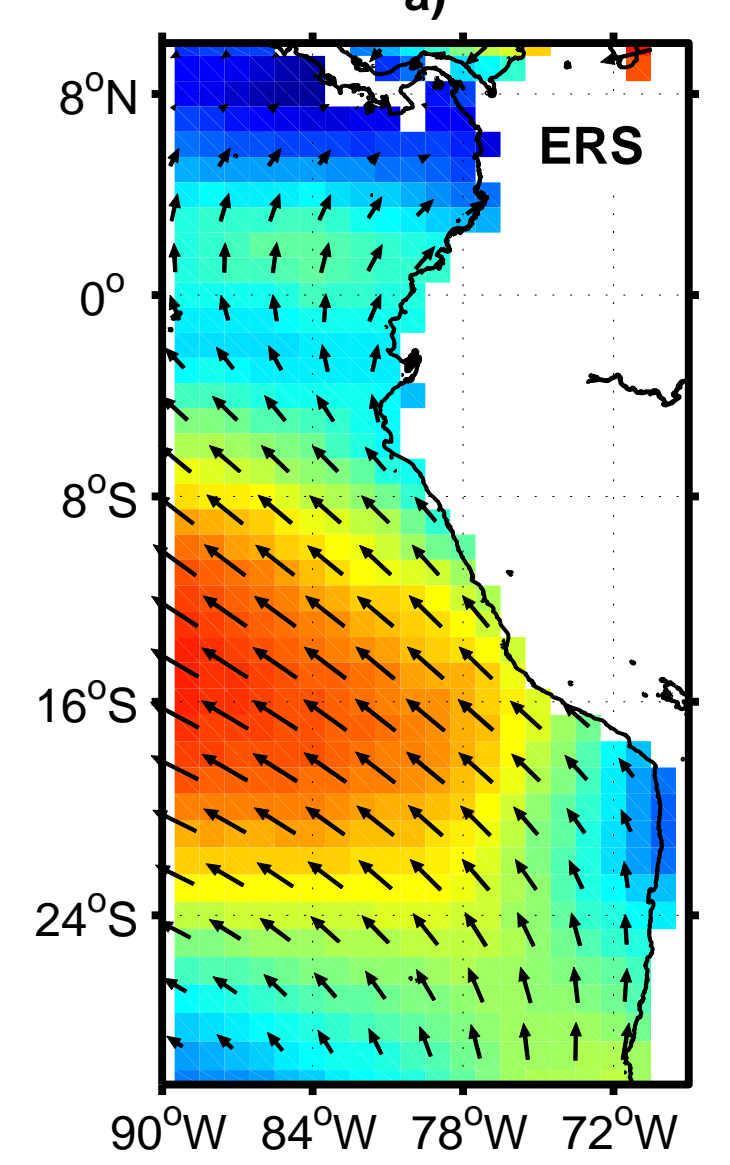

d)

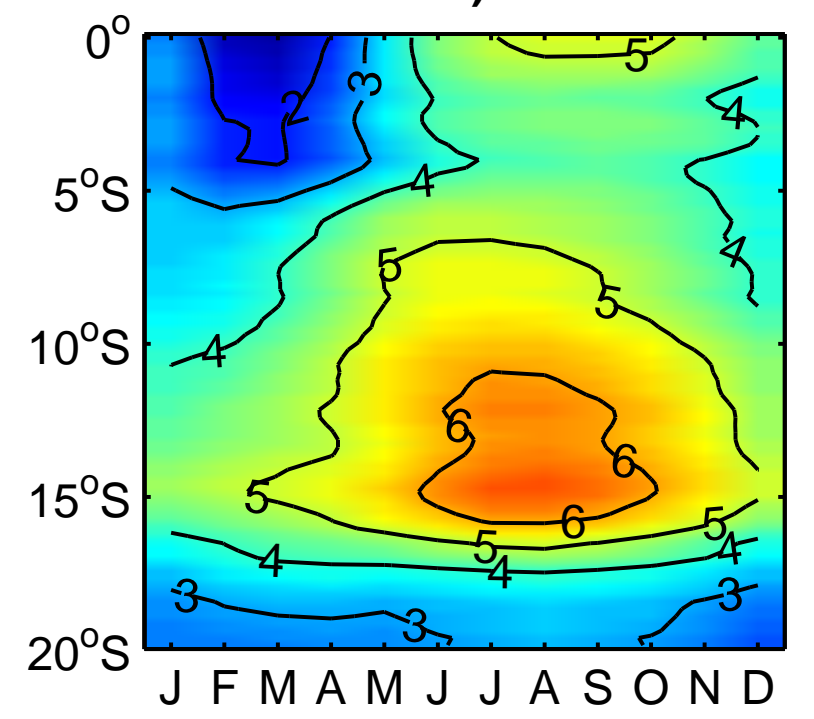

b)

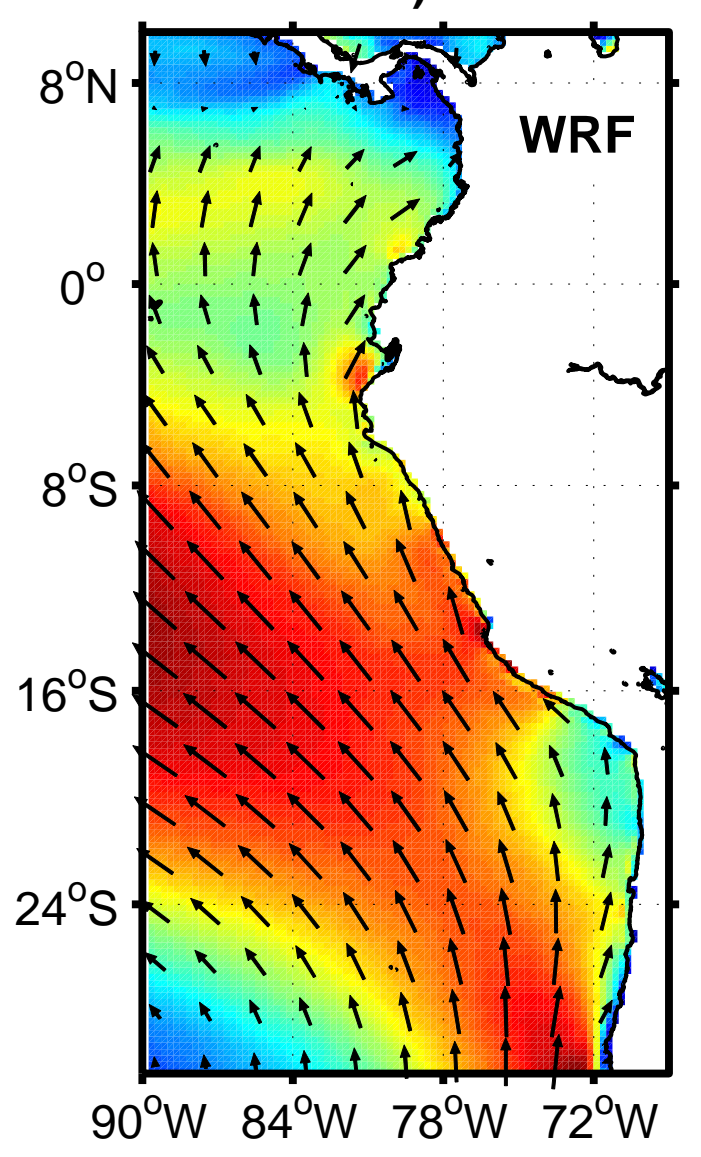

e)

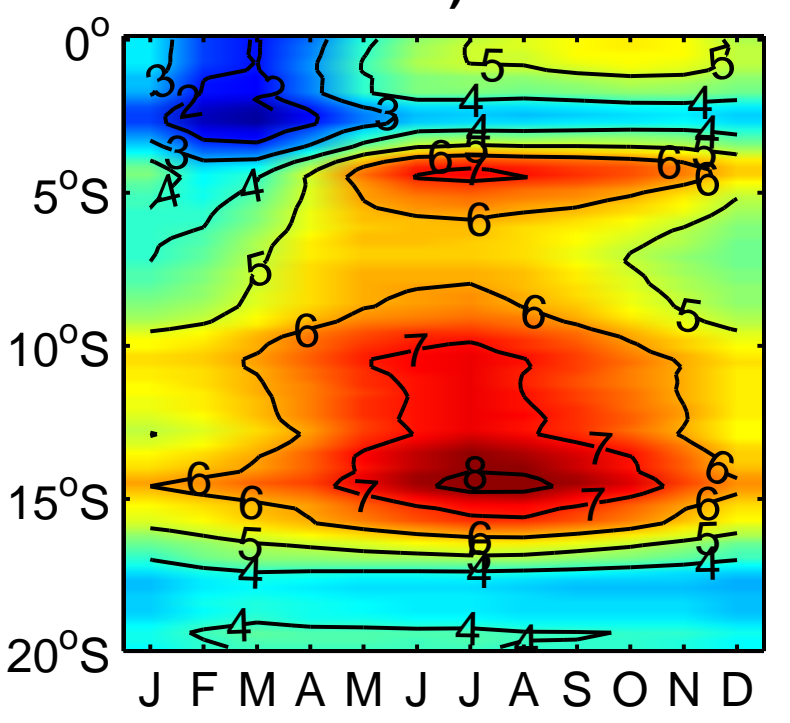

c)

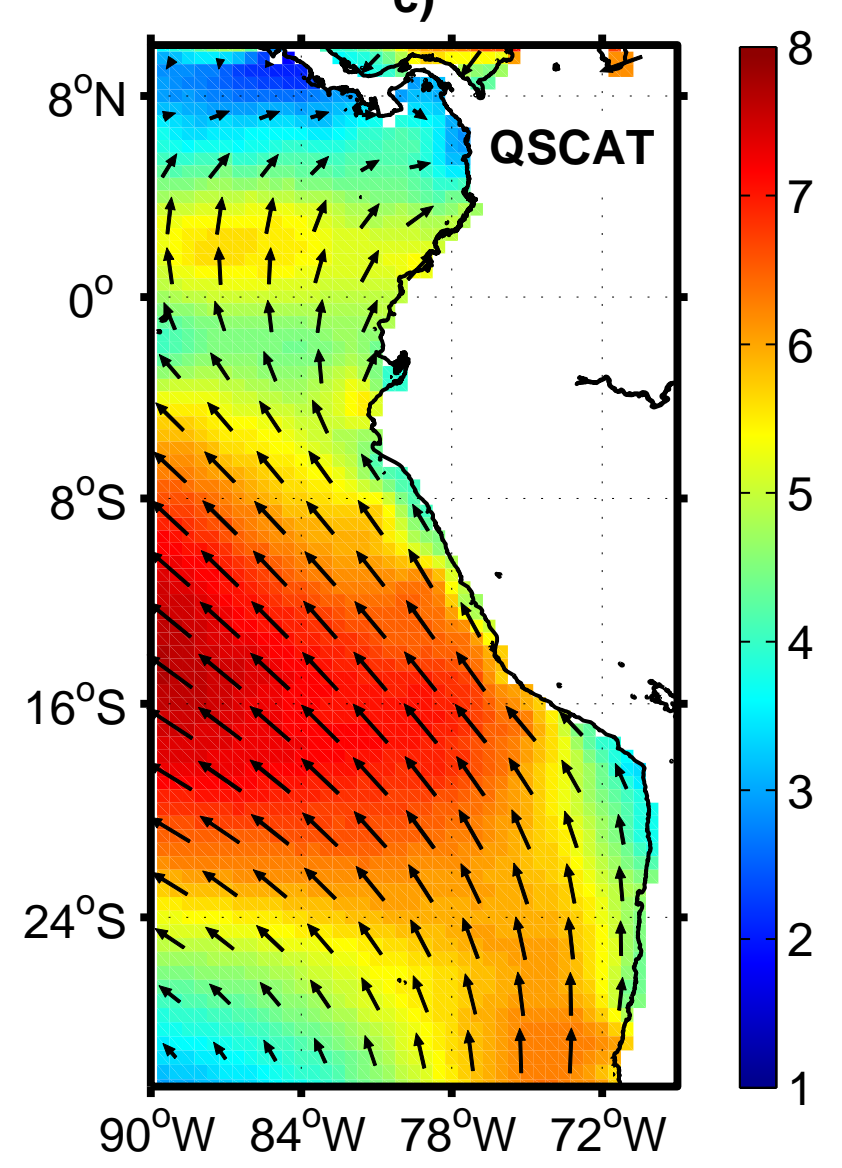

f)

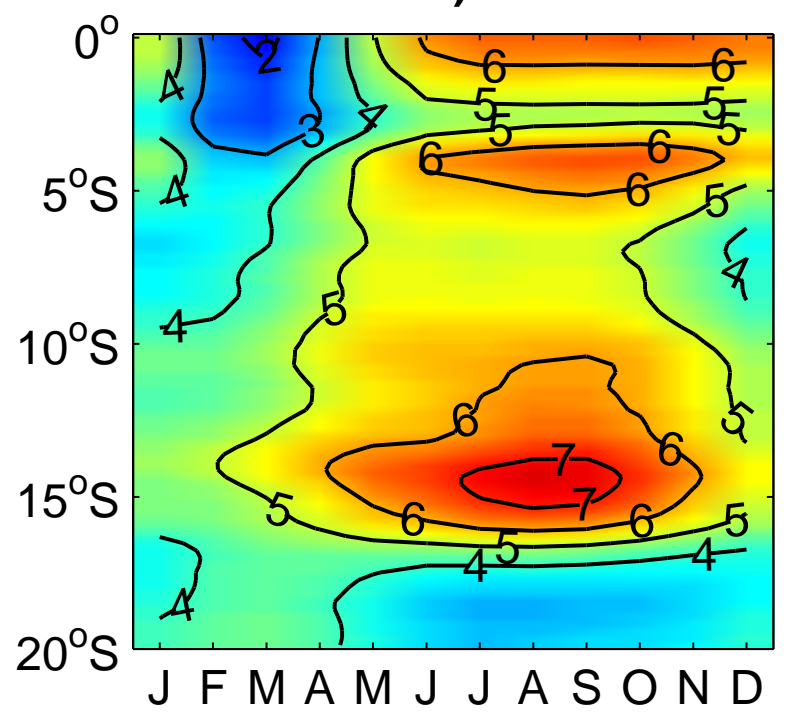


a)

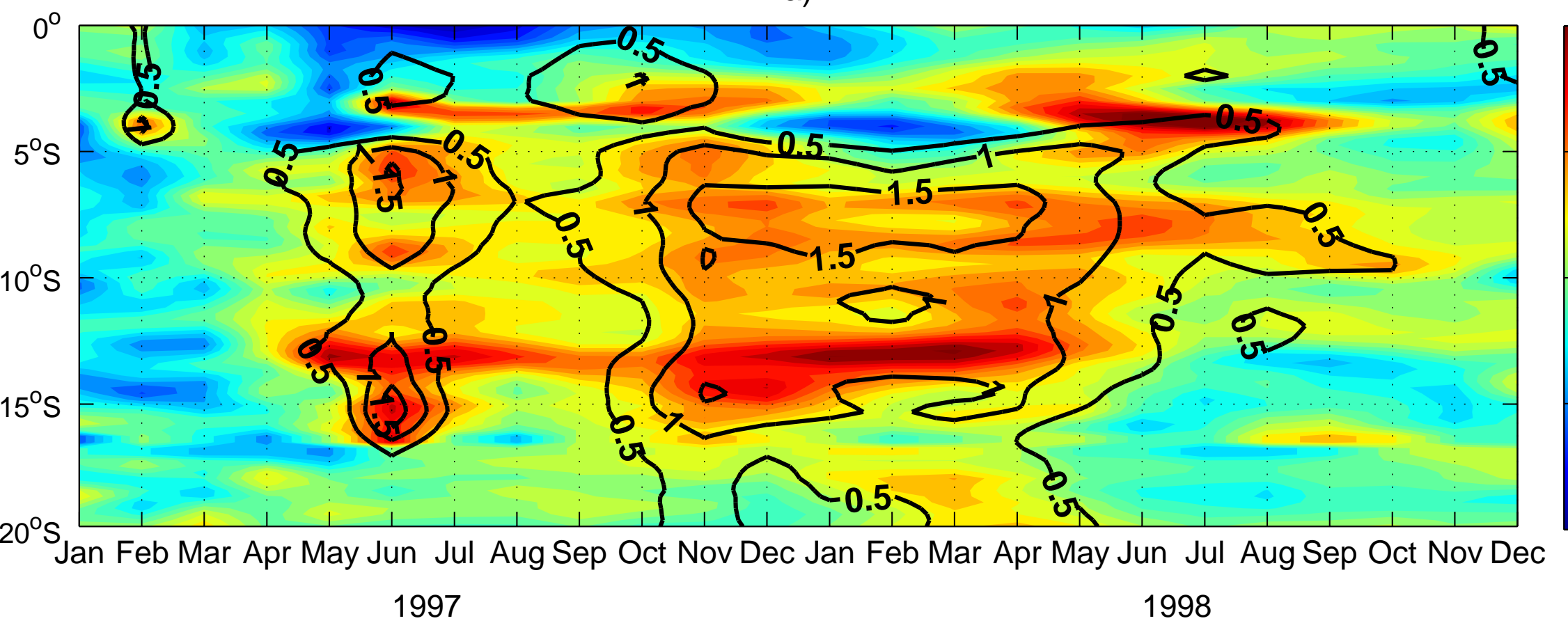

b)

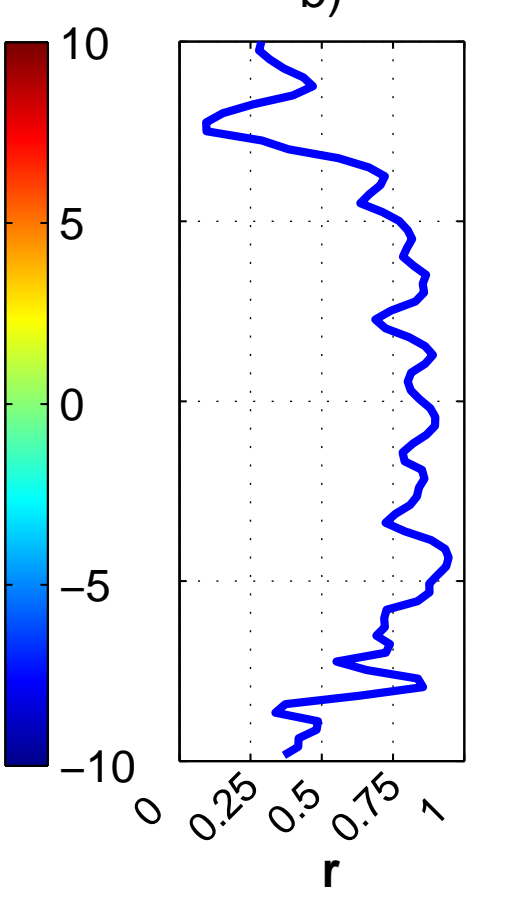




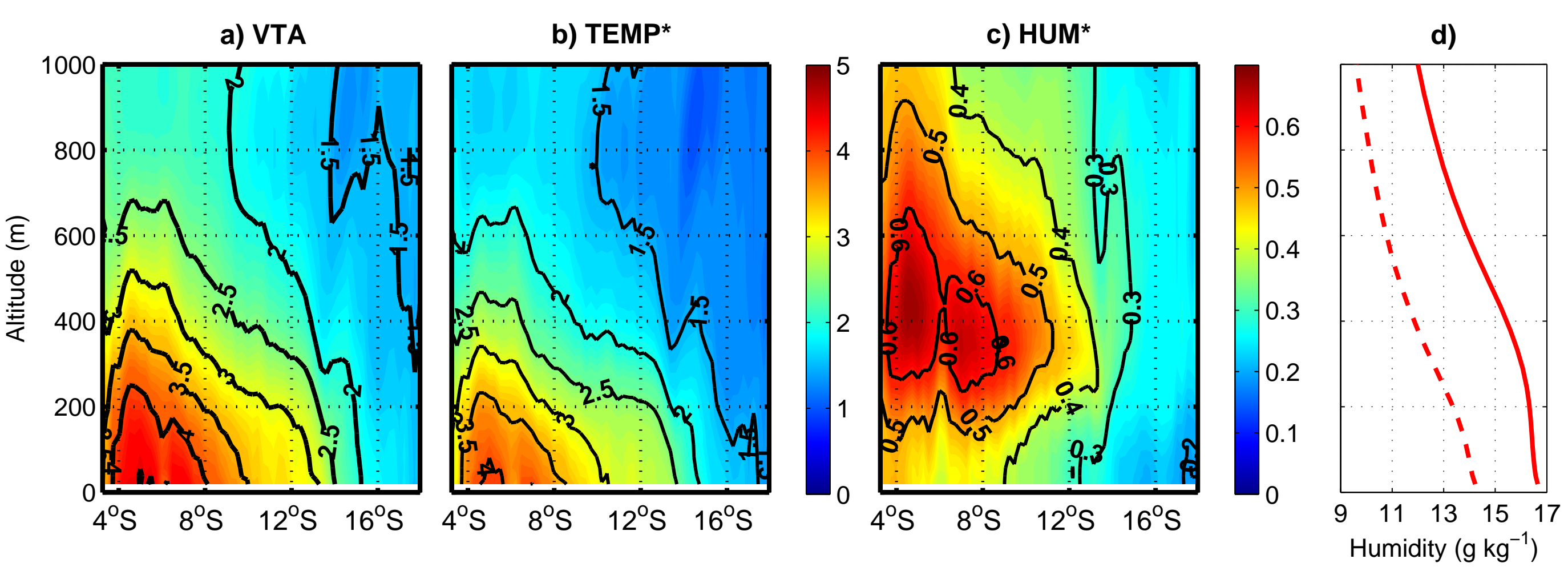




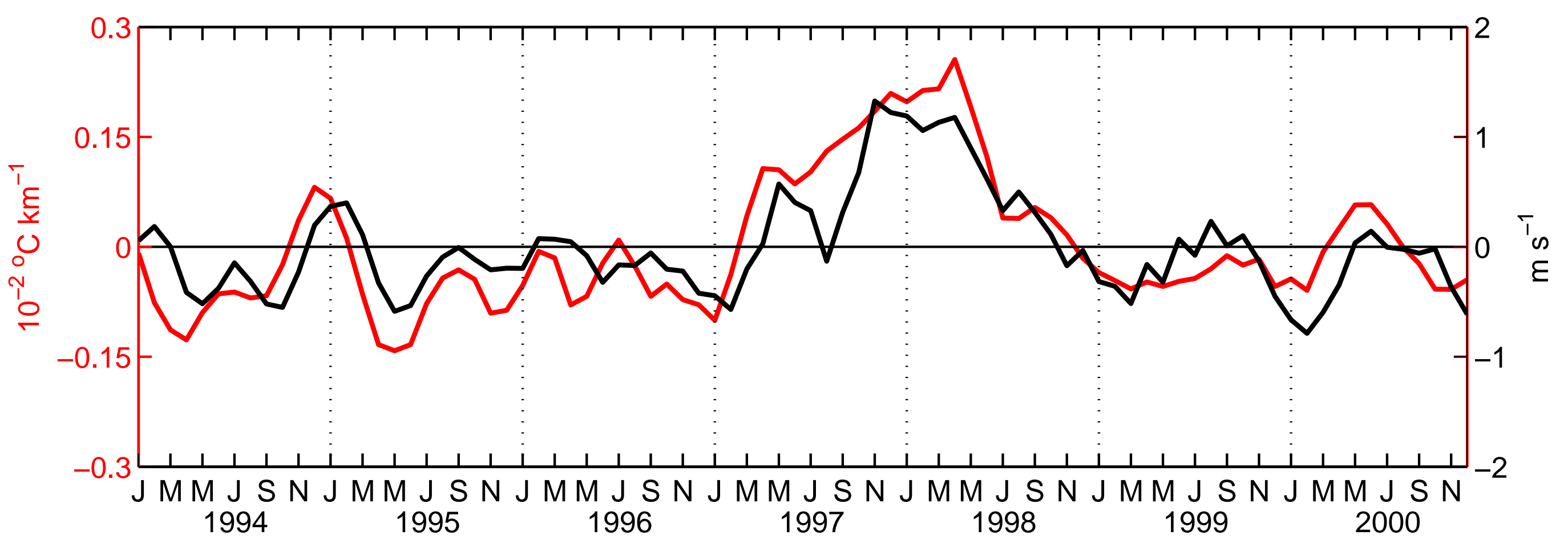




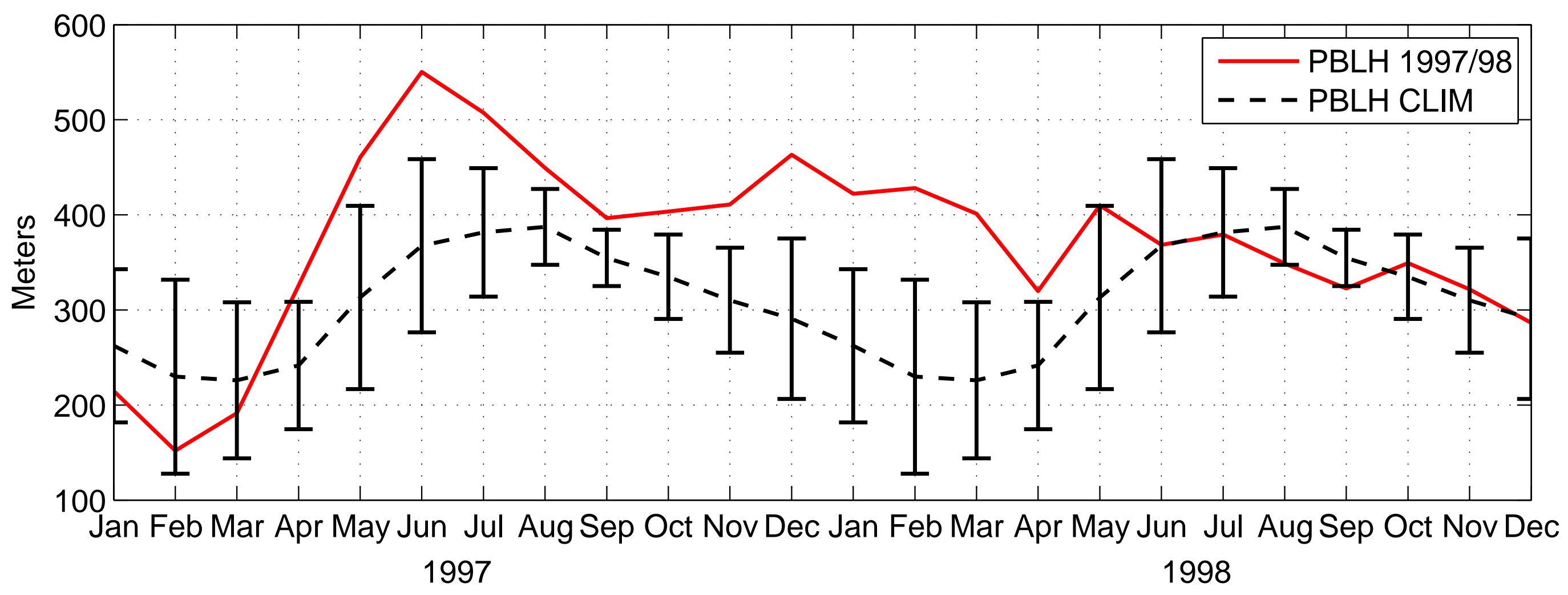


a)

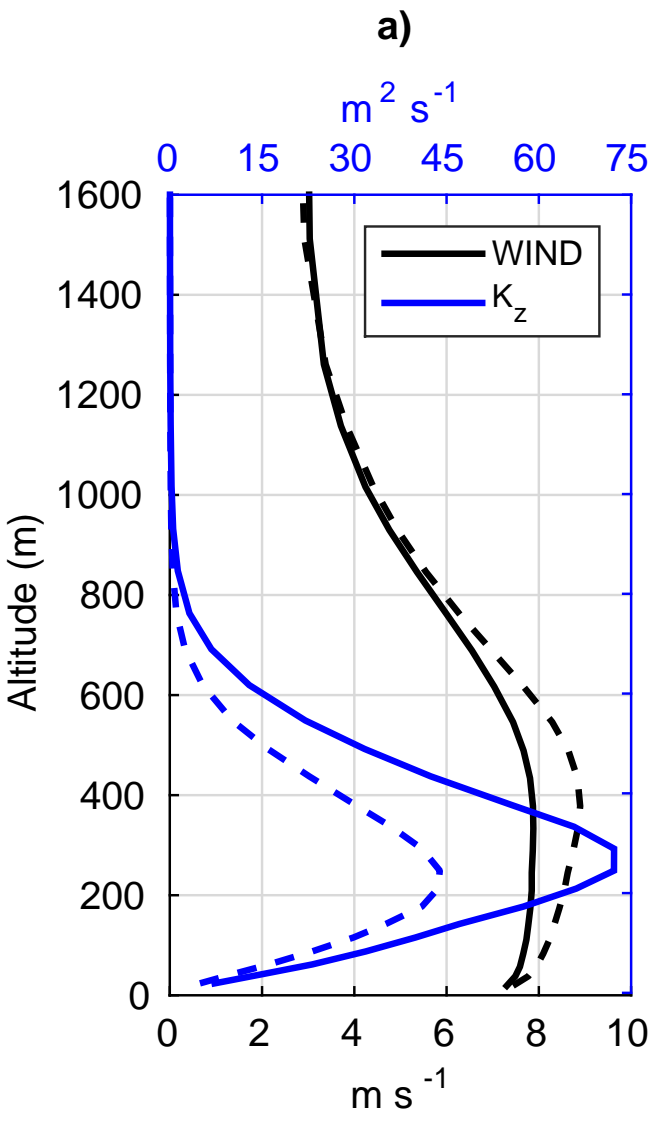

b)

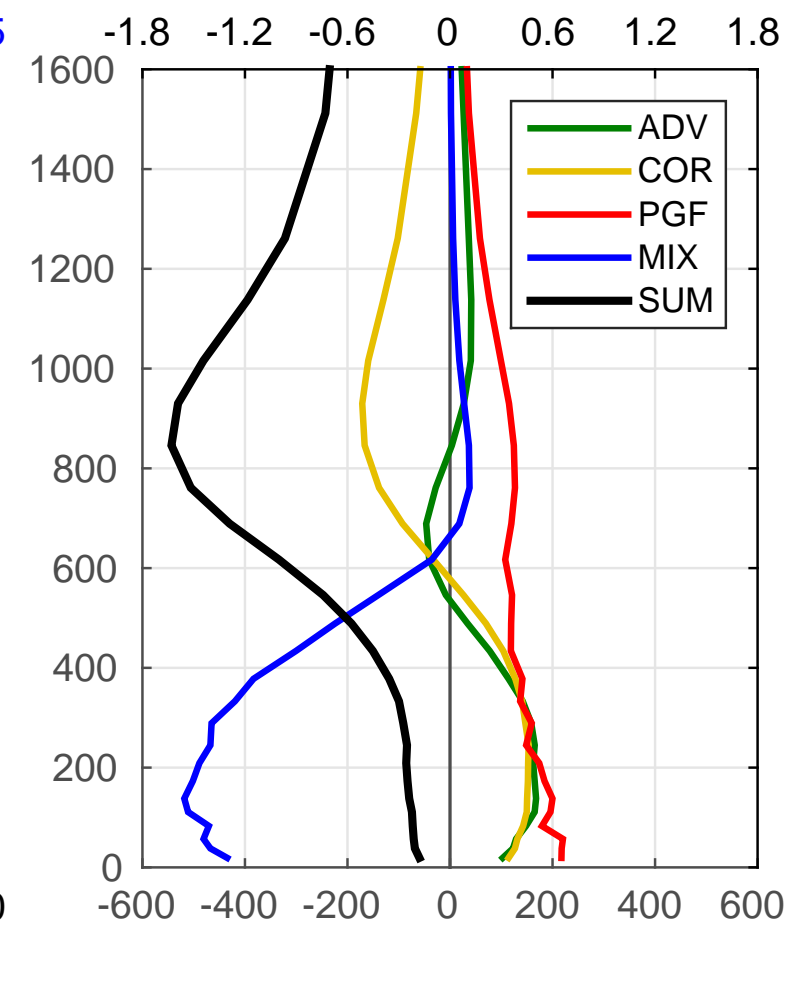

c)

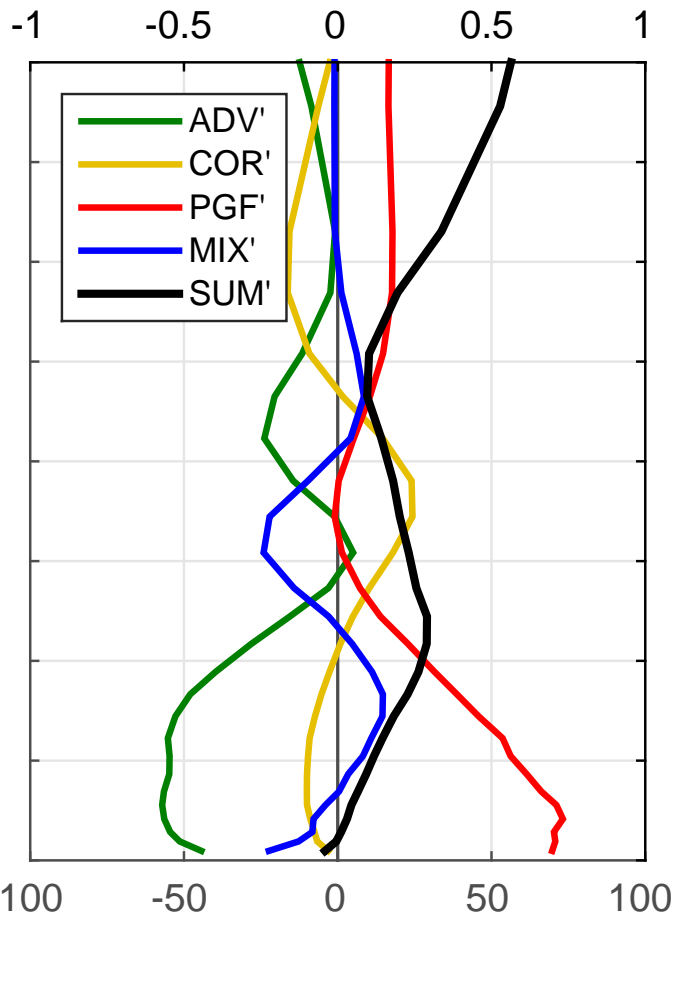

d)

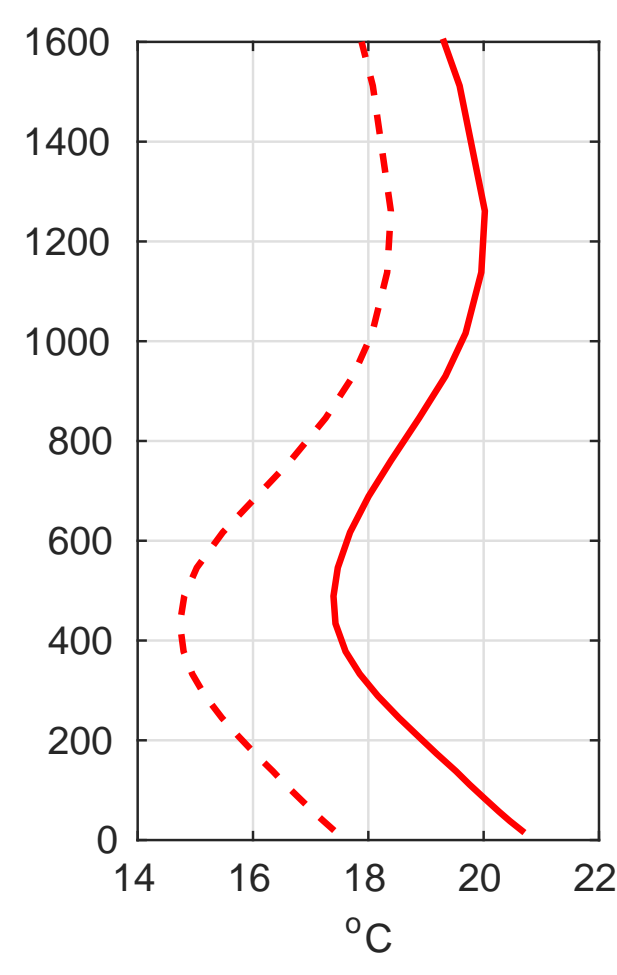




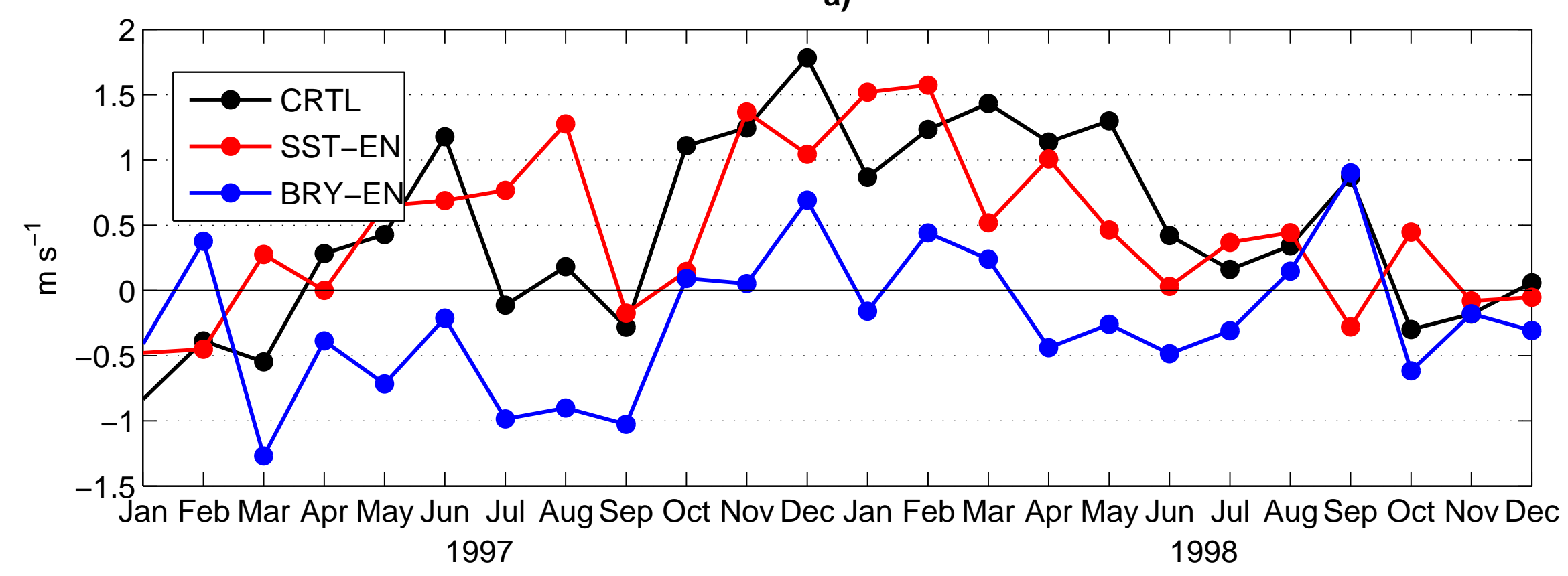

b) JA-1997

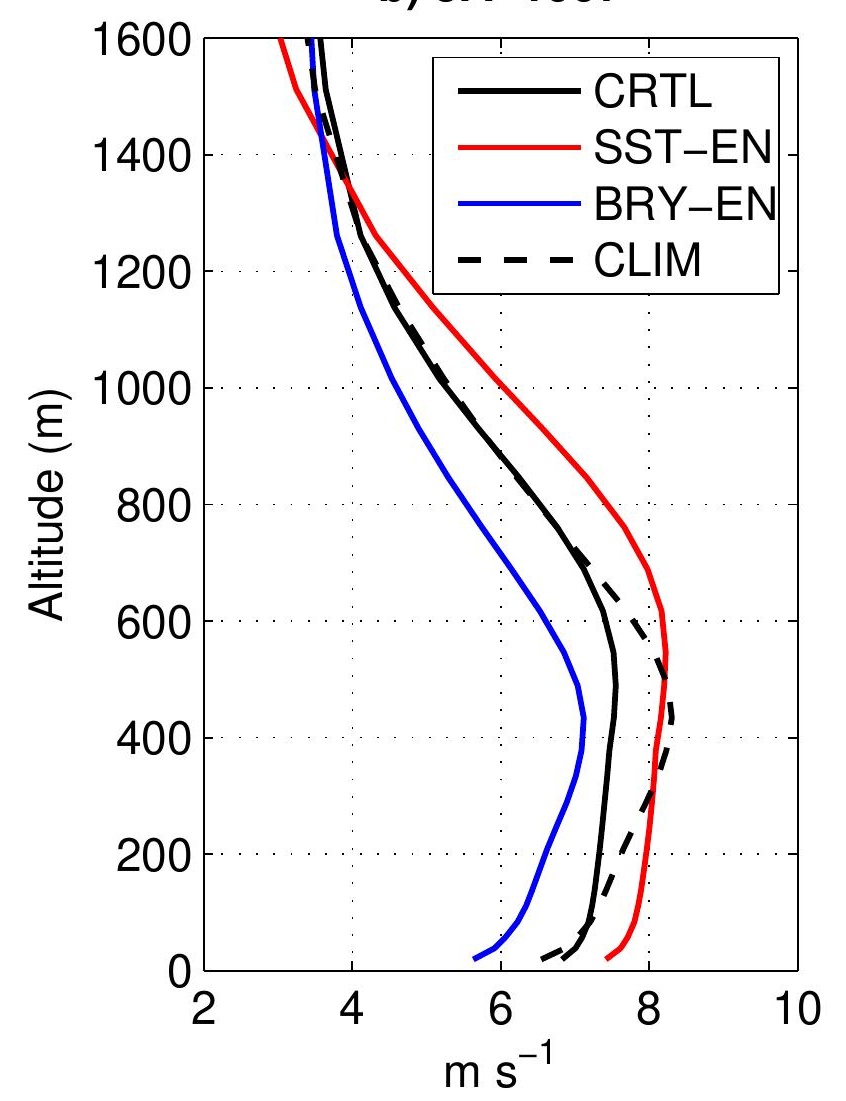

c) NDJF-1997/98

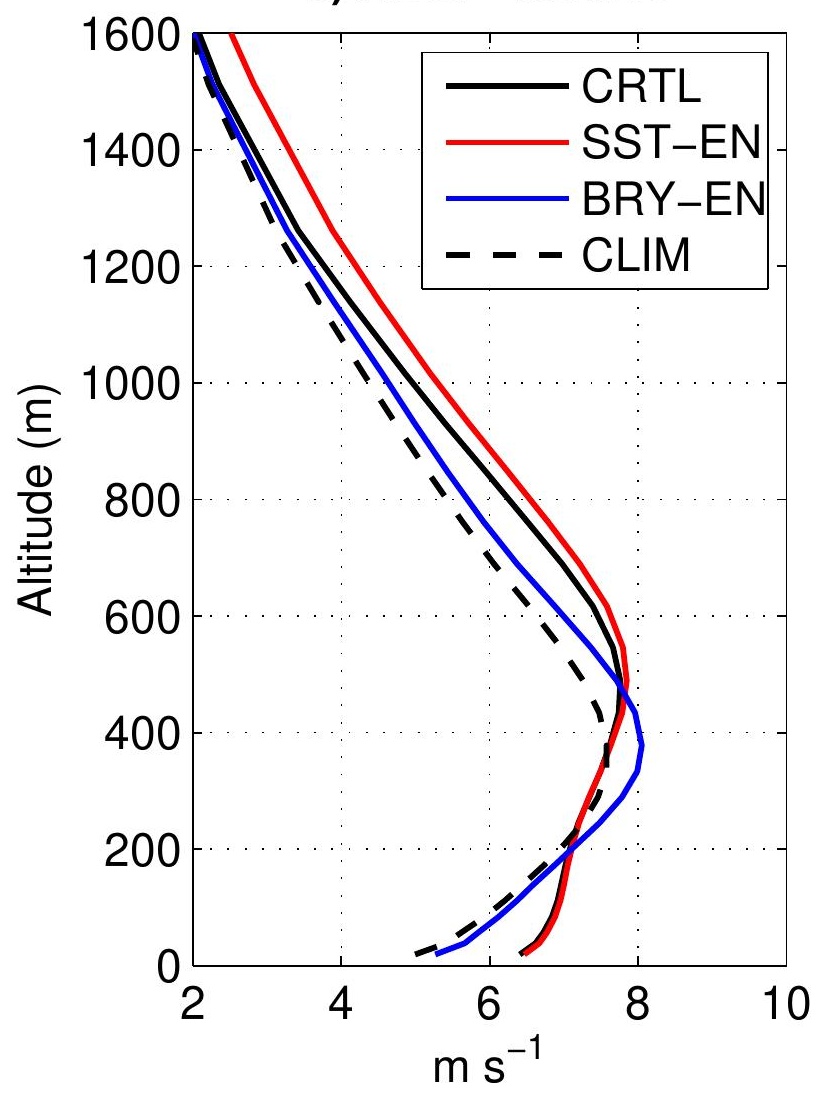


a)

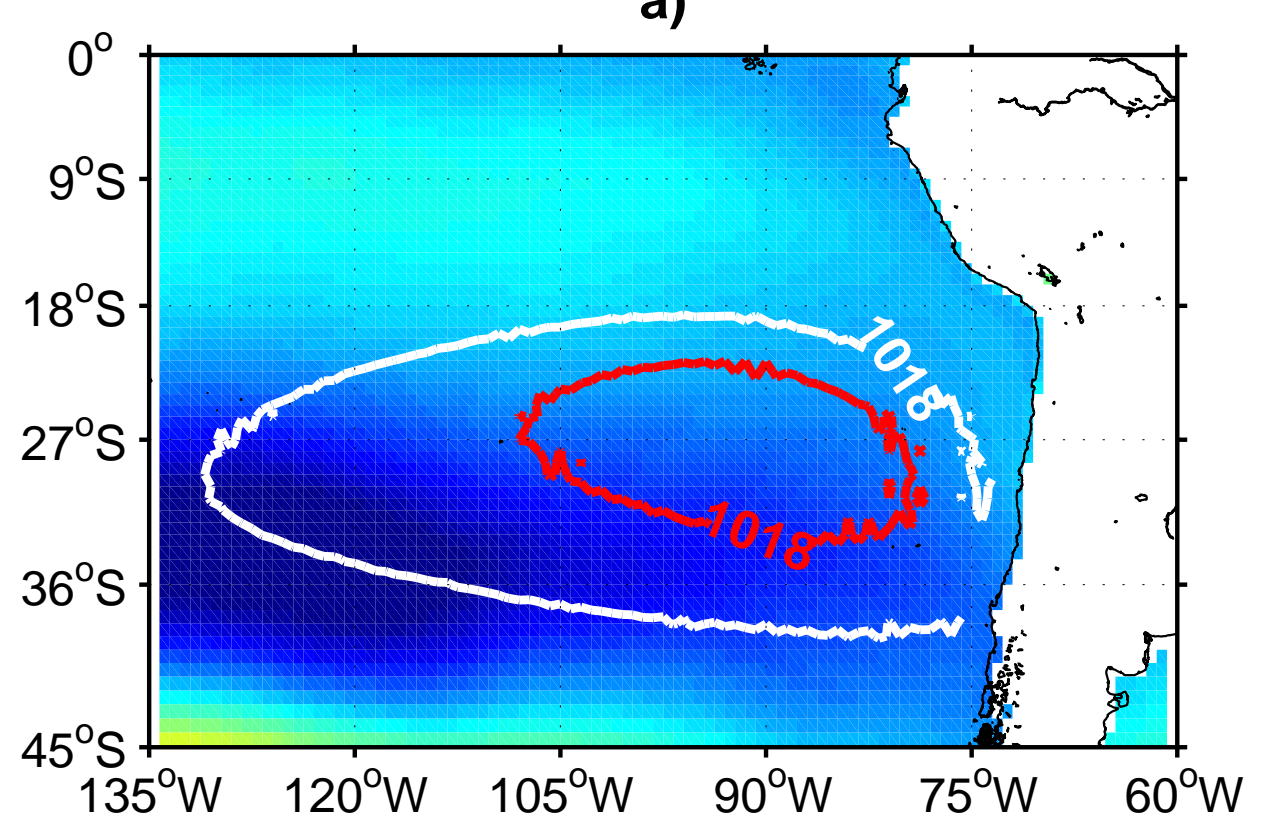

b)

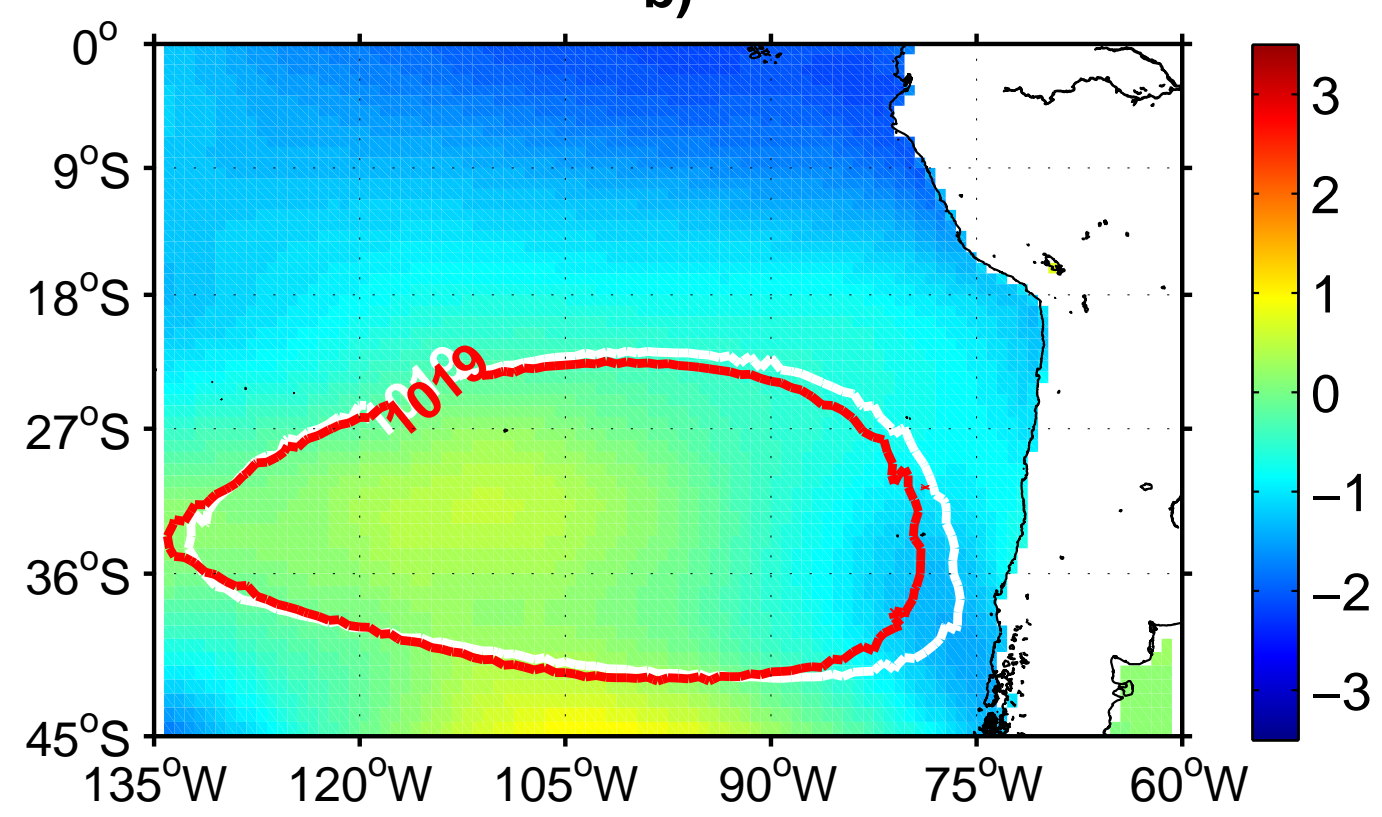



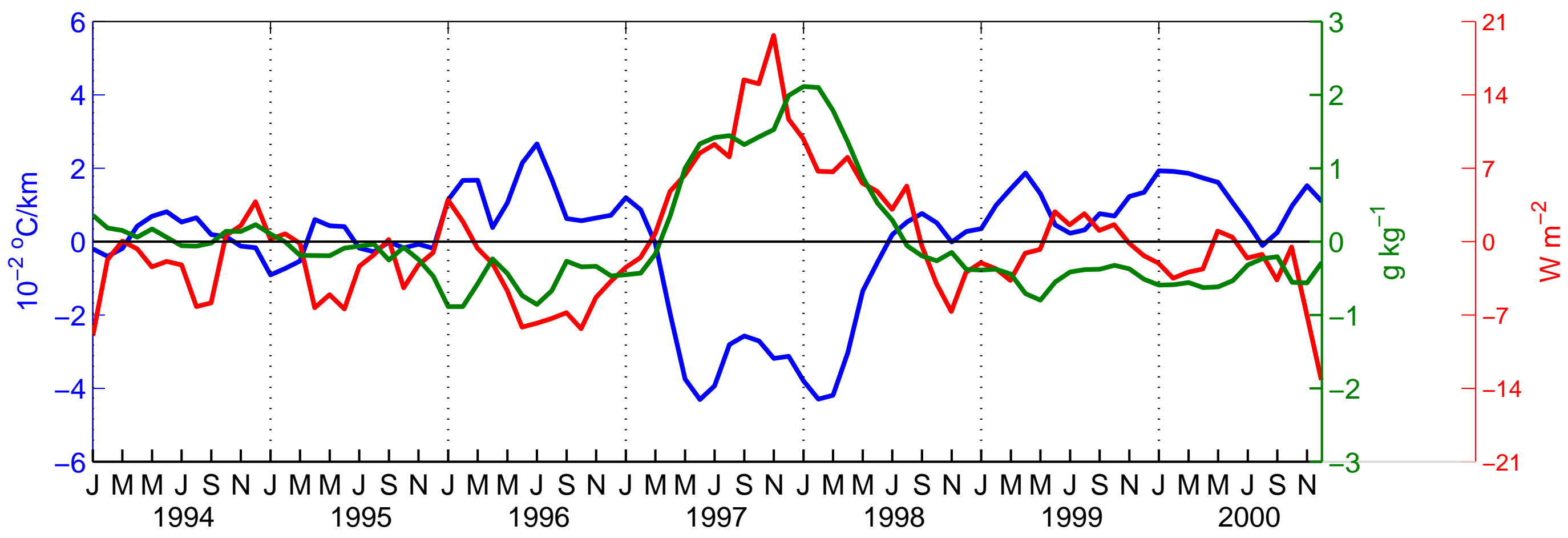


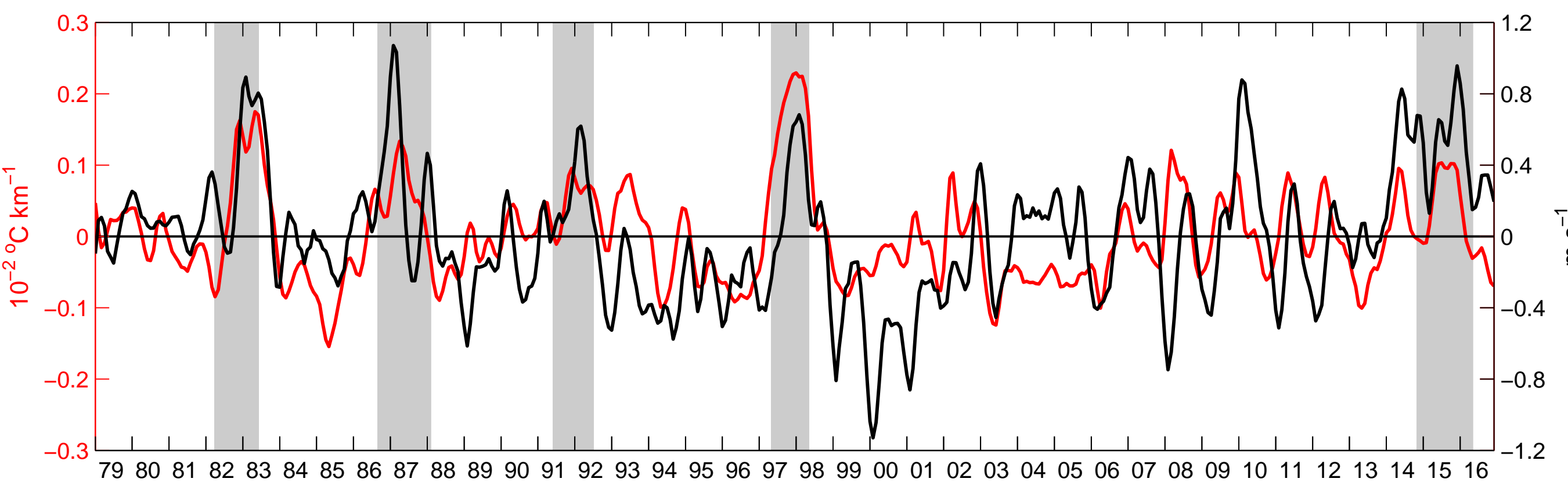


Table 1. Parameterizations used in WRF model for the simulations.

\begin{tabular}{|l|l|l|}
\hline \multicolumn{1}{|c|}{ Processes } & \multicolumn{1}{c|}{ Scheme } & \multicolumn{1}{c|}{ Reference } \\
\hline Shortwave Radiation & Dudhia scheme & Dudhia (1989) \\
\hline Longwave Radiation & RRTM scheme & Mlawer et al. (1997) \\
\hline Microphysics & $\begin{array}{l}\text { WRF Single-Moment 6-class } \\
\text { scheme }\end{array}$ & Hong and Lim (2006) \\
\hline Cumulus & Betts-Miller-Janjic scheme & Janjic (1994) \\
\hline Surface Layer & MYNN surface layer & Nakanishi and Niino (2009) \\
\hline Land Surface & Noah Land Surface Model & Chen and Dudhia (2001) \\
\hline Planetary Boundary Layer & MYNN Level 2.5 PBL & Nakanishi and Niino (2009) \\
\hline
\end{tabular}

